\title{
Doing business in Libya: Assessing the nature and effectiveness of international marketing programs in an evolving economy
}

\author{
Izzudin Busnaina ${ }^{\mathrm{a}}$, Tony Woodall ${ }^{\mathrm{b}, *}$ \\ a Department of Marketing, Faculty of Economics, Benghazi University, P.O. Box 13080, Benghazi, Libya \\ ${ }^{\mathrm{b}}$ Division of Marketing, Nottingham Business School, Nottingham Trent University, Burton Street, Nottingham NG1 4BU, United Kingdom
}

\section{A R T I C L E I N F O}

\section{Article history:}

Received 1 August 2014

Received in revised form 25 November 2014

Accepted 13 February 2015

Available online 17 March 2015

\section{Keywords:}

Country-of-origin (brand)

Libya

Major domestic appliances

Marketing strategy

Marketing tactics

Standardization/adaptation

\begin{abstract}
A B S T R A C T
The aim of this paper is to investigate, in one emerging Arab economy (Libya), the strategic and tactical choices of MNE (multinational enterprise) domestic appliance brands and, also, the attitudes of local consumers toward those choices. Various choice characteristics are investigated - including marketing mix standardization/adaptation - and, also, country-of-origin brand (COB). To establish extant organizational choices, local representatives of four established brands were interviewed and survey responses from 609 consumers were analyzed. No statistically discernible relationship between standardization/adaptation choices and consumer attitude toward marketing programs was found, but the study identified one especially successful brand that appeared to owe its achievements to an especially holistic approach to marketing that demonstrated 'fit' with the market concerned. Coincidentally, findings also address the conventional country-of-origin wisdom, and this is investigated/speculated upon accordingly. This is one of few marketing studies concerning Libya, and it adds to the limited literature on an increasingly relevant region.
\end{abstract}

(c) 2015 Elsevier Ltd. All rights reserved.

\section{Introduction}

Marketing insight regarding the Arab world has only recently accrued (earliest studies include Djursaa \& Kragh, 1998; Elbashier \& Nicholls, 1993; Michell, Lynch, \& Alabdali, 1998; Souiden, 2000) and most has inevitably focused on countries that are more clearly aligned with the West, such as Kuwait (e.g., Al-Wugayan, Pleshko, \& Baqer, 2008), Jordan (e.g., Zabadi, Shura, \& Elsayed, 2012) and the United Arab Emirates (e.g., Khraim, Khraim, Salim, Al-Kaidah, \& AlQurashi, 2011). Further, although studies addressing consumer issues in Arab contexts have recently increased (e.g. Al Ganideh, 2012; Ghanem, Kalliny, \& Elgoul, 2013; Tolba, 2011) literature in this area, generally, is limited (see Birnik \& Bowman, 2007; Ellis \& Zhan, 2011), and this is especially surprising given that the Arab market is becoming increasingly materialistic and that the collective Arab economy is now estimated to be the world's eighth largest, with a GDP approaching \$2.5 trillion (Mahajan, 2013). Our understanding, especially, of how international firms

\footnotetext{
* Corresponding author. Tel.: +44 01158484313.

E-mail address: Tony.Woodall@ntu.ac.uk (T. Woodall).
}

approach such markets and how local consumers respond to these approaches is sparse, especially in those countries perceived to represent a more capricious business environment (e.g. Syria, Algeria and Libya: Dinnie, 2011).

This study is applied in a setting that, for reasons of recent social and political turbulence, represents a particularly interesting context for research. In the decade leading up to recent conflicts, and following a period of relative isolation, Libya actively encouraged international trade (Porter, 2007), yet there is a relative lack of research addressing either period (US \& FCS, 2006), and this alone makes Libya an intriguing context for investigation. Recent events, clearly, mean that the commercial world will be watching developments in the region with interest (Dinnie, 2011), and the focus of this paper is timely, given that it provides insight into an area that can only attract further attention (KPMG, 2013).

\section{Aims of the study}

It has been suggested that the key to success in international markets is, above all, 'being global but acting local' (Cateora \& Graham, 2005; Kefalas, 1998; Svensson, 2002). The pursuit of competitive advantage has always focused on developing marketing programs that recognize different customers' needs and 
expectations (Kotler, 2003) and a compromise, therefore, that effectively weighs both standardization and adaptation may well be the best option. Finding the right balance by which to operationalize this most complex of challenges (Harris \& Attour, 2003; Schmid \& Kotulla, 2011; Theodosiou \& Leonidou, 2003), however, is never easy, and standardization will be more easily realized in some contexts than in others (Viswanathan \& Dickson, 2007). It is not surprising, therefore, that much recent research has focused on identifying the key criteria influencing adaptation/standardization decisions (e.g. Brei, Avila, Camargo, \& Engels, 2011; Chung \& Tsai, 2009; Helm \& Gritsch, 2014).

Understanding how suppliers interpret and manifest the need for adaptation and, further, how consumers react, have become vital issues - not least because suppliers are now moving into emerging markets where potential for growth is substantial (Wooldridge, 2010), but where, coincidentally, potential for dissension/misconstrual is equally large (e.g. Arab/Muslim markets: Busnaina, Youssef, \& Woodall, 2010; Mahajan, 2013; Marinov, 2007). Successful marketing is focused, primarily, on consumer preference and the degree to which product characteristics are valued (Kotler, 2003), but not everything, though, can be easily changed. Balabanis and Diamantopoulos (2004) suggest consumer preference embodies a wide spectrum including brand name, supplier image, country-of-origin (COO), price, availability and ethno-nationality; and that brand and national identity are often conflated in the consumers' mind (see also, Knight, 1999). The way that brands, and their offerings, are perceived, therefore, is a combination of both the (relatively) mutable and the (relatively) fixed, with marketing programs and COO at opposite ends of the adaptation spectrum, and understanding how these work in concert can perhaps provide for a more comprehensive insight into consumer attitudes than by considering each, alone.

This paper looks to extend understanding of international marketing in the Arab region by pursuing a range of questions concerning one specific consumer goods category (large home appliances), in one specific Arab market (Libya). Our research questions are:

1. To what degree do foreign companies adapt/standardize marketing programs for Libya?

2. What are the factors that have influenced corporate decisions concerning standardization/adaptation for Libya?

3. How, and to what extent, might Libyan consumer attitudes toward overseas brands be impacted by marketing program standardization/adaptation decisions?

4. What are the effects of key product identity characteristics (brand name and COO) on Libyan buying attitudes and decisions?

As the paper develops, key issues relating to the above are surfaced and subsequently expressed as testable propositions. These propositions, drawn from the wider internationalization literature, are then subjected to quantitative and/or qualitative examination within a Libyan market and conclusions are drawn accordingly. Findings are derived both from interviews with local agency managers (issues related to questions 1 and 2), and from a major consumer survey ranged over Libya's three major urban conurbations - Tripoli, Benghazi and Sabha (issues related to questions 3 and 4).

\section{Conceptual review and propositions}

Essentially, the aim of this study is to explore how MNE marketing programs are both determined and perceived and, as a focus for analysis, the 'standard' $4 \mathrm{P}$ marketing mix is employed. Although some have applied the wider, 7P/services, mix (e.g. Vrontis, Thrassou, \& Lamprianou, 2009) the 4Ps framework is the most ubiquitous in consumer research and has long been the subject of study internationally (e.g. Chan \& Cui, 2004; Cheon, Cho, \& Sutherland, 2007; Gaski \& Etzel, 1986; Herche, 1994; Tan \& Sousa, 2013). Organizational marketing mix adaptation tactics have been studied at the individual (e.g. brand - Sandler \& Shani, 1992: distribution Rosenbloom, Larsen, \& Mehta, 1997; Shoham \& Brencic, 2003: pricing - Theodosiou \& Katsikeas, 2001; Zou \& Cavusgil, 1996: product - Lages, Silva, \& Styles, 2009; Shaw \& Richter, 1999: promotion - e.g. Karande, Almurshidee, \& Al-Olayan, 2006; Solberg, 2002), dual (e.g. product and promotion - Chung, 2009; product and distribution - Calantone, Cavusgil, Schmidt, \& Shin, 2004 and aggregate (e.g. Kustin, 2010; Powers \& Loyka, 2007; Zou \& Cavusgil, 2002) level, though studies have focused almost exclusively on internal perspectives - either exploring management preferences and/or evaluating impact on organizational (mostly financial) performance. Contributions seeking to understand relationships between global brand adaptation/ standardization choice and buyers' attitude toward these are, though, less common.

\subsection{Adaptation versus standardization: key issues}

The standardization versus adaptation debate has run now for many years, and continues still (e.g. Brei et al., 2011; Schmid \& Kotulla, 2012; Virvilaite, Seinauskiene, \& Sestokiene, 2011). Some commentators (e.g. Usunier, 2000; Viswanathan \& Dickson, 2007) suggest that the nature of recent macro-environmental changes has given rise to progressive buyer behavior homogenization and, further, that failure to recognize and take advantage of an emerging global culture could leave businesses at a disadvantage (Levitt, 1983; Kotler, 1986; Ozsomer \& Simonin, 2004). Others suggest that local circumstances demand adaptation (e.g. Askegaard \& Madsen, 1998; Ghemawat \& Thomas, 2008; Souiden, 2002) and that some degree of change may be unavoidable (Cateora \& Graham, 2005; De Mooij \& Hofstede, 2002), whilst Kustin (2004) has suggested that standardization and adaptation are both viable, even essential, options for building a global presence across diverse national contexts. And, of course, there is the question of feasibility - even though standardization, for example, may be a preferred option, practicalities may demand otherwise (Siraliova \& Angelis, 2006).

These questions apply too, where ethno-religious, rather than national, factors constitute the nature of market character. For example, although Arab countries are geographically distinct, suppliers have tended to adopt a broadly Middle Eastern perspective (Fastoso \& Whitelock, 2010) hoping, as a consequence, to benefit from the effect of shared ethnic characteristics (norms/values derived from Islam; tribal customs; Islamic and Ottoman history; the Arabic language: Metz, 1987 ) and pan-Arab promotional media opportunities (Melewar, Turnbull, \& Balabanis, 2000). Vrontis et al. (2009) suggest that both internal and external factors will affect such decisions, and that the dilemma has become increasingly convoluted, with the range of factors impacting standardization/adaptation decisions now more complex than ever. This leads to the following propositions:

Proposition P1a. The nature of marketing program adaptation undertaken by an NME operating in an overseas market varies according to the characteristics inherent within the market concerned. 
Proposition P1b. The extent to which an MNE adapts/standardizes its marketing program for an overseas market varies according to the characteristics inherent within the market concerned.

At the most basic level product role/function is a key factor determining extent of standardization/adaptation to be adopted (Cayla \& Arnould, 2008; Hise \& Choi, 2010) as, clearly, when a product meets a universal need less adaptation is required, and standardization opportunities are enhanced. Here, of course - as with all other considerations - researching the market is critical, and for international markets, especially, where local knowledge and a 'feel' for what works no longer applies, an appropriate enquiry and exploration platform is key to effective marketing program planning (Jain, 1989; Ozsomer \& Simonin, 2004; Theodosiou \& Katsikeas, 2001).

Mode of entry, too, represents a critical point of strategic choice (Canabal \& White, 2008). When companies perceive market uncertainty they may be inclined either to ignore that market or, alternatively, prioritize control via full direct investment (Brouthers \& Brouthers, 2003; Taylor, Zou, \& Osland, 2000). The literature suggests, though, that globally aspirational brands should be flexible, and that the most controllable choices (e.g. direct entry) may not always be possible (Jain, 1989). Indirect approaches (e.g., local agency) have, by contrast, proved effective in politically ambiguous/developing markets (Schuh, 2000), and though this may constrain strategic choice (Griffith, Chandra, \& Ryans, 2002) the benefits of exploiting local expertise can be great, especially for ultra-competitive categories such as electrical appliances. Competition, of course, impacts strategy generally (Whitelock \& Jobber, 2000), not least when associated with standardization/adaptation decisions (Viswanathan \& Dickson, 2007). According to Jain (1989) the absence of competition encourages standardization but, of course, competition factors vary for different markets, and this then compounds decision making complexity (Theodosiou \& Leonidou, 2003).

Once primary issues have been considered - the impact of adaptation on product attractiveness and/or utility; the range of mode-of-entry options available; the nature, strength(s) and extent of the competition - the organization will need to ensure it is able to nurture and sustain its marketing program to ensure ongoing effectiveness. Clearly, headquarters-subsidiary relationship can have a major impact (Lee \& MacMillan, 2008), and the relative degree of conflict and/or accord will serve to either constrain or facilitate operational choice (Kustin, 2010; Shoham, Brencic, Virant, \& Ruvio, 2008). The quality of this relationship will, to a great extent, determine how well adaptation plans are effected and accepted locally (Jain, 1989), substantially influencing brand strategy, not least in respect of implementation and control (Dibb, Simkin, Pride, \& Ferrell, 2006; Kotler, 1999) - an issue of especial concern for international marketers, who are likely to be operating in unfamiliar, disparate and structurally complex market networks (Chung, 2009). Paradox and contradiction are inherent within nationally diverse markets and there exists a tension between the benefits to be achieved through centralized monitoring and decision making (Solberg, 2000), and the value to be had from localized understanding/interpretation of consumer intelligence (Arnold, 2000). The following propositions are advanced:

Proposition P2a. Mode of entry has a significant impact on adaptation/standardization priorities.

Proposition P2b. Goods category/characteristics have a significant impact on relevant adaptation/standardization priorities.

Proposition P2c. Awareness of competition has a significant impact on adaptation/standardization priorities.
Proposition P2d. HQ-subsidiary relationship has a significant impact on adaptation/standardization priorities.

One of the primary aims of this study is to assess consumer attitudes toward marketing practice adopted by, or on behalf of, overseas brands in Libya. Essentially, it looks to address the issue of "how marketing is doing' (Gaski \& Etzel, 1986) in the eyes of buyers. Thus, there is a need to understand how each company's marketing mix is perceived by consumers or, more precisely, how these consumers judge its relevance to, and impact upon, their personal context. This is a well-established area of concern in consumer research and has been the subject of study both in the East (e.g. Chan \& Cui, 2004; Varadarajan \& Thirunarayara, 1990) and in the West (e.g. Barksdale \& Darden, 1972; Gaski, 2008; Gaski \& Etzel, 1986, 2005) where a longitudinal study, spanning more than two decades of business in the USA (Gaski \& Etzel, 2005), established that consumers' attitude toward marketing was a highly potent metric demonstrating a strong positive relationship with general economic confidence and wellbeing.

The extent, though, to which marketing programs that are adapted to accommodate local needs are found more (or less) appealing to target consumers is less frequently addressed. Clearly, the primary reason why an organization, or brand, would wish to adapt, rather than standardize, must be because that organization/ brand feels it could better satisfy the needs of local consumers (Armstrong \& Kotler, 2008). There is certainly some evidence to suggest that not adapting, especially in respect of 'promotions' (and, more specifically, advertising), can have a detrimental effect (e.g. Mostafa, 2011) and it has been demonstrated that differences in national culture are frequently associated with variations in consumer behavior, to the extent that this needs acknowledgment via the adaptation of marketing propositions (De Mooij \& Hofstede, 2002; De Mooij, 2003). Lindridge \& Dibb (2003), Steenkamp \& Hofstede (2002), and Peter \& Olson (2008) have all suggested that when a marketing program is adapted and/or tailored to address local needs, then it can positively impact both market share and profitability, and some notable MNE success stories (e.g., Philips product adaptation in Japan - Kotler, 1986; US company advertisements in the European Union - Siraliova \& Angelis, 2006) have been attributed to specific aspects of marketing mix adaptation.

It has been further noted that even for countries that might be considered culturally similar, subtle differences in customer needs/attitudes might occasionally, and unexpectedly, surface (Viswanathan \& Dickson, 2007), though securing the customers' approval may not simply be a function of catering to distinctive needs. Both Solberg (2000) and Fang, Wade, Delios, \& Beamish (2007) have demonstrated that subsidiaries with a long history of local association are able to gain 'deep' market intelligence and, consequently, obtain a better understanding of the local customer. It's also suggested (e.g. Alpert, Kamins, Sakano, Onzo, \& Graham, 2001) that pioneer brands in international markets (e.g., USA in Japan) are better positioned to understand/take advantage of positive customer attitudes and preferences. The following propositions reflect these perspectives:

Proposition P3a. The more an MNE brand is adapted to address local context, the more positive is customer attitude toward that brand's marketing mix.

Proposition P3b. The more an MNE brand is adapted to address local context the greater is the number of customers buying, or likely to buy, products associated with that brand.

Proposition P3c. The longer a MNE brand operates in a particular market the more likely it is that consumers have a positive attitude toward that brand's market offering. 


\subsection{Country of origin}

For international markets, Felzenstein, Hibbert, \& Vong (2004) consider perceived $\mathrm{COO}$ to be the fifth element of the marketing mix, acting as a distinct and powerful adjunct to the 'conventional' 4Ps, notably for a select band of product categories; for example, motor cars, wine and electrical goods. It is suggested that, as COO cannot be 'designed in', it is not integral to 'product', but can be independently manipulated as a discrete marketing resource to enhance (or spoil, if not manipulated effectively) product perceptions. COO is, according to Balabanis, Mueller, \& Melewar (2002) intrinsic to a brand's identity and exerts a powerful symbolic effect. Koubaa (2008) and Lopez, Gotsi, \& Andriopoulos (2011) have revealed that $\mathrm{COO}$ has a significant effect on brand perception, and that this effect differs between brands and countries.

There is evidence, too (see Essoussi \& Merunka, 2007), suggesting consumers in developing markets view products from mature economies more favorably than those from home. Ettenson (1993) found evidence of this in Eastern Europe in the early 1990s, and parallels may be drawn here between the lifting of the 'iron curtain' and the recent phenomenon known as the 'Arab spring'. In a Nigerian study (context: televisions and motor cars), Okechuku \& Onyemah (1999) demonstrated that COO is significantly more important than other product attributes (including price) in determining consumer preference, coincidentally revealing that African brands projected a determinedly negative image and were rated substantially lower than those from more well-developed economies. Rosenbloom \& Haefner (2009) demonstrated across a range of consumer goods, in a variety of emerging/transitional economies, that brands from the USA and Japan were most trusted.

It should be noted though that brands/products may be 'hybrid' (Chao, 1993), or have 'multi-country affiliations' (Phau \& Prendergast, 2000), meaning that country of assembly/manufacture and country of design might differ. Evidence as to how consumers perceive this, though, and which particular affiliation, or combination of affiliations, have the greatest impact, is mixed (Essoussi \& Merunka, 2007). The issue is further confounded, of course, by the extent to which consumers are aware of these factors (Magnusson, Westjohn, \& Zdravkovic, 2011) and by the relatively unpredictable nature of the processes they use to reconcile any ambiguity (e.g. d'Astous \& Ahmed, 1999), but both Phau and Prendergast (2000), and Srinivasan, Jain, \& Sikand (2004) determined that, for most consumers, perceived brand headquarters location (country of origin of brand - $\mathrm{COB}$; as opposed to COM - country of manufacture) resonates most strongly and, consequently, it is believed that this is most relevant to the present study.

Preference for foreign brands in developing markets will partly be a function of marketing communications/global media but, also, may reflect the impact of 'pioneer' brands from past eras. In Libya, for example, it has been suggested that consumers remember USA brands with perhaps unexpected fondness, and recall products once common in the Libyan market as being of high quality (US \& FCS, 2006). For political reasons Western goods were discouraged in the early 1980s (Metz, 1987) and have only recently been reintroduced (Central Intelligence Agency, 2010). It would perhaps not be a surprise, therefore, if relevant brands were to suffer 'guilt by stereotypic association' (Cristel \& Dale, 2010) and just as likely be reviled as revered (Kalliny \& LeMaster, 2005; Klein, 2002). There is, though, evidence that the tension between a comfortable life supported by strong and reliable global brands, and economic and political imperatives concerning the consumption of homeproduced goods, is not easily resolved (Assad, 2007). Given the mixed and complex relationship that has existed between Libya and the 'outside world' over the past few decades, brand name and
COB are of particular interest. The three following propositions address this area.

Proposition P4a. There is a direct and positive relationship between attitude toward a country's image and consumer attitude toward marketing programs of brands associated with that country.

Proposition P4b. Positive consumer attitude toward COB translates into greater sales for brands associated with that COB.

Proposition P4c. The more a 'brand country of origin' (COB) is preferred the more $\mathrm{COB}$ acts as the primary reason for purchasing products associated with that $\mathrm{COB}$.

\subsection{Study framework}

The framework below (Fig. 1) depicts, (a) key attributes of interest and (b) key relationships pertaining to this study, and links the immediately preceding conceptual review with the research questions addressed in the Introduction. Each of the four questions (Q1-Q4) is also represented as a propositional field (P1-P4) for which associated testable propositions have been developed.

\section{Research context and strategy}

\subsection{Research context}

This paper seeks to explore how Libyan consumers react to both purposefully (4Ps, brand-name) and naturally (COB) occurring marketing characteristics of overseas brands. Major appliances (refrigerators, televisions and air-conditioners) are the focus for study, primarily because consuming such goods is considered characteristic of a 'modernizing' economy (Waheeduzzaman, 2006) - and the Arab world, generally, exemplifies this category. Since 2003, and the lifting of UN sanctions, Libyan economic reform has progressed substantially (Central Intelligence Agency, 2010), and the country has worked hard to re-integrate with the global business community (Porter, 2007). Libya's laws concerning foreign trade, investment, and commercial identity were relaxed both in 2000 and in 2013, and this once-closed economy is attracting increased interest from abroad (Attwood, 2012; Rennack, 2006). For the 2012/2013 academic year - and notwithstanding continued unrest - the Libyan government continued to expand the number of scholarships for Western universities (to more than 5000, according to the Libyan Ministry of Higher Education, 2012) so despite - or perhaps because of both past (Gadhafi's fractious relationship with the West) and recent (Libya's 2011 uprising) events, the general trajectory of its post-millennial history suggests an increasingly global presence. Data was collected immediately preceding the Arab Spring, capturing an environment that, coincidentally, was approaching commercial and economic stability, but - politically and socially was on the cusp of significant change.

For consumer electricals the years 1951-1976 were a 'golden age' for Libya, with many well-known brands - including GE, Braun, Philips, Goldstar (now LG) and Sharp - competing in an open and inviting market. In 1977 Libya became a totalitarian socialist economy, and via state-controlled wholesalers and retailers enforced the circulation of goods that were sourced either locally or from sympathetic regimes in Asia/Eastern Europe. Only after 1991 was the private sector encouraged, and only from 2000 onwards did the appliance market assume fully open status. Mode-of-entry choices were expanded and a small number of brands (Hitachi, Philips, LG and Sharp) have opened local agencies 


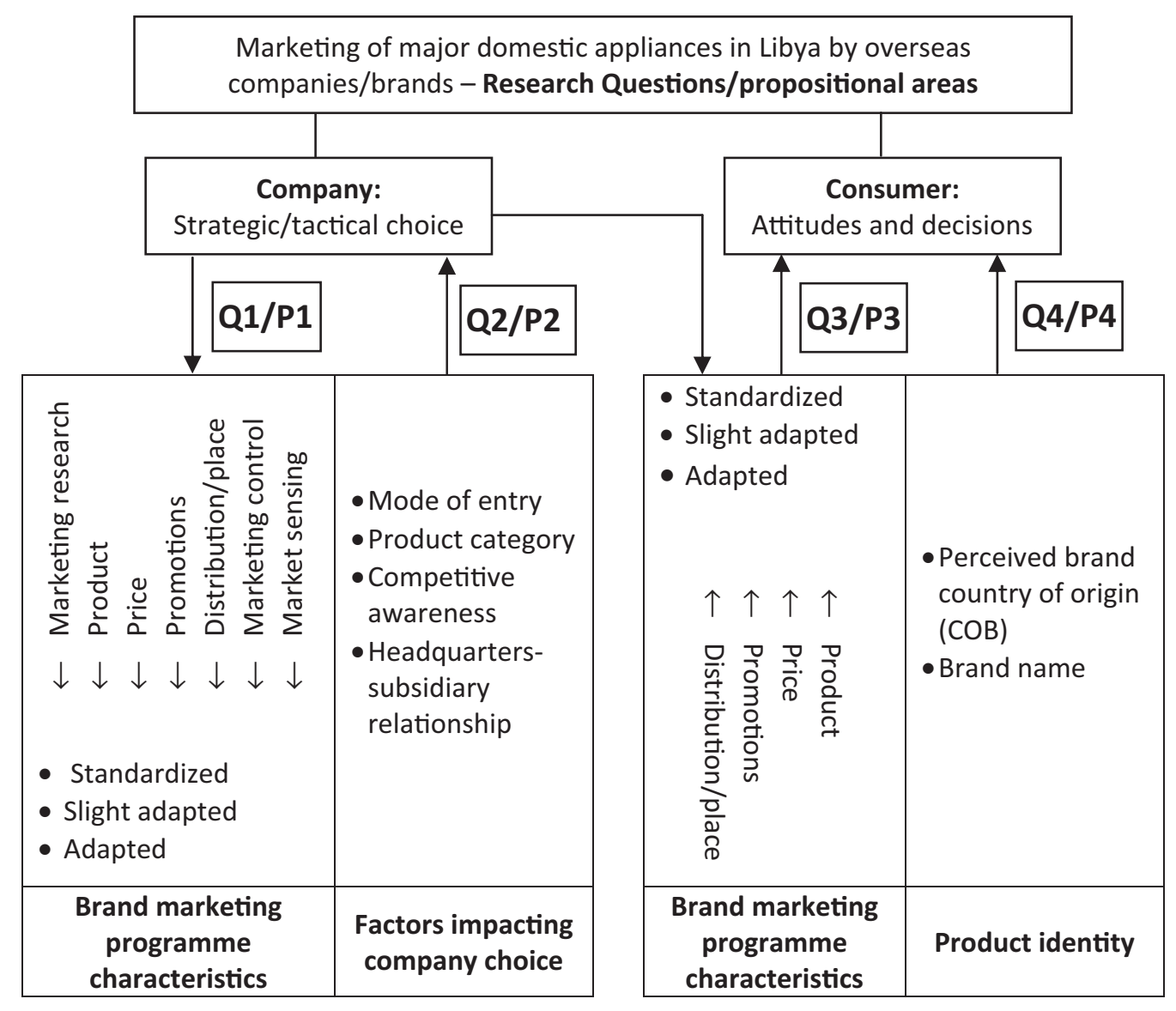

Fig. 1. Study framework.

in the hope of becoming structurally established within the country. A variety of other well-known brands (including Daewoo, Sony and Westinghouse), and less well-known brands from other emerging economies (e.g. China, India), operate on a purely import basis. Turkey, Libya itself, and Egypt represent a Middle East presence which (see Table 7) is slight but starting to grow.

\subsection{Research strategy}

Fieldwork was conducted in two phases; the first to establish the extent to which local agency appliance brands orient/ undertake marketing efforts specifically for the local market; and the second to address attitudes and preferences of Libyan consumers. Although phase two was entirely quantitative phase one incorporated qualitative data too, and in both cases investigations began via a review of the extant literature to establish points of reference for pertinent research constructs. All questions/items were abstracted from prior studies - primarily on the basis of established validity/reliability, though item wording was, in some cases, adjusted. In order to help assure content validity, six academic/marketing expert reviewers were deployed (DeVellis, 2003; Theodosiou \& Katsikeas, 2001) - 3 native, but bi-lingual, from Libya, plus 3 native from the UK/USA - and a pilot was run using 90 consumers. For the survey the experts agreed with both the direction of causality between variables, and also the formative/reflective nature (Jarvis, McKenzie, \& Podsakoff, 2003) of the measures to be used. Methodology, findings and analysis are reported below as two separate studies: Phase 1 (qualitative study) and Phase 2 (quantitative study, including input from Phase 1).

\subsection{Phase 1 - Qualitative study}

\subsubsection{Methodology}

Firstly, interviews were conducted with those responsible for managing local marketing activity on behalf of the four home appliance brands that have operational bases in Libya (see Table 1). Other major brands access the market through importation and, consequently, local representatives have no direct understanding of branding decisions/activities, so are not included in these investigations.

Interview structure was based upon a number of existing frameworks pertinent to both the nature of, and factors determining, suppliers' adaptation/standardization decisions (Jain, 1989; Kotler, 1986; Luna \& Gupta, 2001; Melewar \& Vemmervik, 2004; Ozsomer \& Simonin, 2004; Schuh, 2000; Siraliova \& Angelis, 2006; Viswanathan \& Dickson, 2007; Zou \& Cavusgil, 2002) and these were tailored to meet the needs of the study. Although relevant frameworks are normally adopted for surveys the relatively small size demanded a more personalized/content-rich approach and it was determined that structured interviews would serve this purpose best - see Appendices 1 (nature) and 2 (determining factors) for interview schedules. A structured format was used primarily to ensure consistency but also to enable ready comparison and conversion into categories for later analyses (see Kemp-Benedict, 2009). This latter was achieved by interpreting answers to indicate submission to one of three distinguishing categories - 'standardized', 'slightly adapted' or 'adapted'. For example, regarding Appendix 1, e) Product Decisions, one interviewee responded in respect of air-conditioner packaging: "yes, the instructions on the pack are in Arabic, and we adjust the 
Table 1

Home appliance brands under investigation in the Libyan Market at time of study.

\begin{tabular}{|c|c|c|c|c|c|c|}
\hline $\begin{array}{l}\text { Company } \\
\text { name }\end{array}$ & $\begin{array}{l}\text { Country of } \\
\text { origin }\end{array}$ & $\begin{array}{l}\text { Global } \\
\text { distribution }\end{array}$ & Interviewee & Mode of entry & $\begin{array}{l}\text { How long in } \\
\text { Libyan market }\end{array}$ & Products offered \\
\hline Hitachi & Japan & 164 countries & Sales Manager & Local Agency & 7 years & Electronics and home appliances \\
\hline Philips & Netherlands & 60 countries & Owner Manager & Local Agency & 18 years $^{\mathrm{a}}$ & Lighting, electronics and home appliances \\
\hline LG & South Korea & 80 countries & Marketing Manager & Local Agency & 17 years & Electronics and home appliances \\
\hline Sharp & Japan & 45 countries & Sales Managers & Local Agency & 7 years & Electronics and home appliances \\
\hline
\end{tabular}

a This company has operated primarily as a supplier of lighting products, and has only recently (last 7/8 years) entered the Libyan home appliances market.

length of the tube between the internal and external unit according to the average of the walls' thickness of Libyan buildings". Conversely, he confirmed they do not adapt core product features (e.g. esthetics and electrical system) and standardize where possible. These responses were interpreted as, "Yes, we do minor packaging adaptation" and "No, we do not adapt the core product"; inferring e) Product Decisions to be 'slightly adapted'.

\subsubsection{Results - Classification criteria}

Table 2 shows how, based on analysis of interview results, selected major appliance brand decisions have been interpreted. This suggests 'place/distribution' to be the only resource fully adapted by all brands, implying each was happy to delegate discretion locally in respect of stocks, flow and outlet choice. Local agencies adopt a flexible distribution approach utilizing both major retailers and small shops, all offering free delivery. Table 2 evidences, though, one significantly different supplier (LG) for which none of the six marketing activity categories remains standardized. By contrast, Sharp and Hitachi (especially) pursue an almost entirely standardized approach.

In addition to revealing adaptation strategy, managers were also asked (see Appendix 1, g) to compare specific factors in respect of home and Libyan marketing programs. Results suggested 'brand name' as the most commonly standardized feature $(M=5.00)$, followed by packaging and physical characteristics $(M=4.75$, 4.25). Place/distribution was least standardized $(M=1.00)$ with managers advising that brands rely substantially on maintaining good relationships with network partners though, again, LG was the most committed supplier.

\subsubsection{Results - Decision factors}

The next stage was focused upon determining key factors influencing suppliers' adaptation/standardization decisions. Firstly, managers were asked which product amendments were thought necessary to facilitate Libyan entry (see Appendix 2, a). All broadly agreed that core product characteristics did not require change, and of the four brands investigated only LG was found to assume a regional design policy for Arab countries.

Given that all four brands had adopted local agency, reasons for this preferred mode of entry were also investigated (Appendix 2, b). All managers reported that brand HQ's were happy with this choice, and there appeared to be no intention to change for the foreseeable future. This reflected a generally cautious approach but was also perceived as a sign of trust in the agencies concerned. In order to evaluate HQ's-subsidiary relationship (Appendix 2, c) interviewees were asked about strategic priorities both for brands and for their Libyan agents. Answers revealed considerable consensus over a range of issues, not least for standardization/ adaptation, and suggested perceived levels of accord were a major factor in determining local marketing program characteristics. The four brands assessed were the only ones from an observed total of thirty seven that were locally based, with most other brands adopting an export-based approach.

Finally, competition-related factors that might impact adaptation/standardization decisions were explored (see Appendix 2, d). Results showed that three brands (Hitachi, Philips and Sharp) evaluate competition at the appliances market level only (direct or category competition), but that LG also addressed possible substitutes - other products in other categories providing alternative spending opportunities (indirect competition). This implied that LG is more aware of the wider impact/nature of competition, and has a more comprehensive view of the market.

\subsection{Phase 2: Quantitative study}

\subsubsection{Methodology}

Primary survey-related aims were (1) to establish the impact of foreign marketing programs on consumer attitudes generally and, more specifically, the extent to which standardization/adaptation decisions might impact attitudes toward those programs, plus, (2) to obtain some insight into the importance/impact of perceived COB. Scales for both aspects of the survey were based largely upon existing measures (see Appendix 2), and self-completion questionnaires were distributed to consumers located in three regional capitals (Benghazi primarily, but also from Tripoli and Sabha). Sampling followed Krejcie and Morgan (1970) and the initial 1157 total suggested a predicted error of just $2.88 \%$. A range of direct administration methods were deployed (in order to enhance response rate) and 609 usable questionnaires, 53\% of the sample, were collected back. The respondent sample profile is as Table 3 .

Initially, consumers were asked to detail major appliances, by brand, that they had recently bought or would imminently purchase ('preferred brand') and these were identified too, according to brand HQ location ('COB' in tables further below).

Table 2

Analysis of marketing programs - brands under investigation.

\begin{tabular}{|c|c|c|c|c|}
\hline \multirow[t]{2}{*}{ Marketing activity } & \multicolumn{4}{|c|}{ Brands under investigation } \\
\hline & Hitachi & Philips & LG & Sharp \\
\hline (a) Marketing research & Standardized & Slightly adapted & Adapted & Standardized \\
\hline (b) Product decisions & Standardized & Standardized & Slightly adapted & Slightly adapted \\
\hline (c) Pricing & Standardized & Slightly adapted & Adapted & Standardized \\
\hline (d) Promotion & Standardized & Slightly adapted & Slightly adapted & Standardized \\
\hline e) Place/distribution & Adapted & Adapted & Adapted & Adapted \\
\hline (e) Marketing control & Standardized & Slightly adapted & Adapted & Slightly adapted \\
\hline Overall level of adaptation/standardization & Standardized & Slightly adapted & Adapted & Slightly adapted \\
\hline
\end{tabular}


Table 3

Respondent sample profile.

\begin{tabular}{llr}
\hline Gender $(n)$ & Male & 318 \\
Marital status & Female & 291 \\
& Single & 402 \\
& Married & 193 \\
Age & Divorced/Widowed & 14 \\
& $18-27$ & 273 \\
& $28-37$ & 245 \\
& $38-47$ & 67 \\
& $48-57$ & 15 \\
Asset Wealth & $58-67$ & 17 \\
& 68 \& over & 2 \\
City location & Percent owning $\geq 1$ Home & 58.8 \\
& Percent owning $\geq 1$ Car & 41.7 \\
& Tripoli & 499 \\
& Benghazi & 50 \\
& Sabha & 60 \\
\hline
\end{tabular}

Note: the estimated 2009 population for Libya is 6.2 million.

Attitude toward marketing programs was assessed using measures (a) to (d) at Appendix 3, each based upon a 5-point Likert scale, and consumers were directed to answer relevant questions - about product features, price, promotional messages and distribution channel characteristics, or place - specifically in respect of their 'preferred brand'. Some items were negatively worded and subsequently reverse-scored. Three free choice questions were also posed (see scale e., Appendix 3) so as to ascertain respondents' perspectives on country image.

As illustrated earlier, the 4Ps constitute the primary focus for studies concerning both organizational and consumer interest in marketing program effect, but it is evident that decisions to buy are influenced by a wider range of factors. It was determined from the relevant literature (e.g. Dawar, Parker, \& Price, 1997; Okechuku \& Onyemah, 1999; Pavlos, Vrechopoulos, \& Doukidis, 2002) that once consumers become aware of their options (via promotions) and have established an appropriate channel for access (place/ distribution) then key decision criteria for the type of goods under consideration are likely to be focused around COB, brand name, safety, price, salesperson's advice, and how up-to-date the product is. A 'second tier' approach, therefore, was also implemented and this involved asking respondents to consider how important these factors were to their buying decisions/intentions. To begin with consumers were asked to identify the three factors they relied on most and, finally, to refine this down to their number one (\#1) criterion.

\subsubsection{Results - Consumer attitude}

Internal consistency of the questionnaire items was assessed using Cronbach's Alpha (DeVellis, 2003) and scale reliabilities were estimated at $0.78,0.76,0.79$ and 0.80 , all conventionally considered acceptable (e.g. Burns \& Burns, 2008; Reynaldo \& Santos, 1999). A variety of further analyses was then deployed in order to triangulate/understand the nature of relationship between brand preference and relative attitude toward the preferred brand's marketing mix. Table 4 shows Libyan consumer attitude toward large appliance marketing practices judged on the basis of local application of the 4P marketing mix.

This suggests a medium level of attitude toward product and distribution ( $M=3.60$ and 3.38 respectively), but relatively low attitude toward price $(M=2.61)$ and, especially, promotional activities $(M=2.38)$. A MANOVA test applied to the data, however, implied no significant difference $(p<0.05)$ between brands. The Wilks' Lambda multivariate test of overall differences among groups was not significant $(F=0.43$; $\mathrm{df}=4$; sig. $=0.981$, with tests of between subject effects for the full corrected model also not significant. There is consequently no indication that brand adherence, based on attitude to the marketing mix, varies across the four suppliers assessed and that all brands impact their adherents similarly. Tables 5 and 6 report on tests using the same attitude data, though this time aggregated according to marketing mix and organized to characterize attitude to both brand and standardization/adaptation category. 198 members of the survey sample had purchased LG's products, whilst for Hitachi, Philips and Sharp numbers were 51, 10 and 11 respectively. 33 other brands were identified by a further 191 consumers but, of course, there is no adaptation data available for these, as mode of entry here is import. Consequently, the marketing mix for these brands is likely to be standardized, given that all are supplied directly via retail networks, and with little or no local/purposive intervention. When considered from a category perspective, therefore, group sizes are 198 Adapted, $21(11+10)$ Slightly Adapted, and $242(191+51)$ Standardized - still low for the Slightly Adapted category, but now more robust for Standardized.

The data is interrogated in two ways. Firstly, a one-way ANOVA was performed so as to compare means both between brands and between standardization/adaptation categories (see Table 5). Requirements for Levene's test for homogeneity of variances were satisfied for both sets of data, and means between groups were found not to differ significantly. For brands, $F(4,604)=0.298$ and $p>0.05$ (0.879), whilst for categories, $F(2,606)=0.201$ and $p>0.05$ (0.818). Post hoc Tukey's HSD tests gave similar results. Secondly a multinomial logistic regression was executed with 'Sharp' used as point of reference for brands, and 'Adapted' as reference for adaptation category (see Table 6). In both instances ratio of valid cases to independent variables exceeded the minimum preferred ratio of 20:1 (115.25:1 and 153.67:1, respectively) and likelihood ratio tests gave no indication of a relationship between dependent and independent variables. For brands, the proportional chance accuracy rate (46.25\%) was slightly exceeded by the predicted accuracy rate but, for categories, prediction (56.4\%) exceeded chance (40.83\%).

Table 4

Relative positive sentiment - the 4Ps.

\begin{tabular}{|c|c|c|c|c|c|c|c|c|c|c|}
\hline \multirow[t]{3}{*}{ Marketing mix } & \multicolumn{5}{|c|}{$\begin{array}{l}\text { Aggregate scores across all suppliers } \\
\text { Scale }=1-5\end{array}$} & \multicolumn{5}{|c|}{ MANOVA - test for between-subject effects: full corrected model } \\
\hline & \multirow[t]{2}{*}{ Weighted mean } & \multicolumn{4}{|c|}{ Supplier means } & \multirow[t]{2}{*}{ Sum of squares } & \multirow[t]{2}{*}{ df } & \multirow[t]{2}{*}{ Mean Square } & \multirow[t]{2}{*}{$F$} & \multirow[t]{2}{*}{$\operatorname{Sig}(p=<0.05)$} \\
\hline & & $\mathrm{H}$ & $\mathrm{P}$ & $\mathrm{L}$ & $\mathrm{S}$ & & & & & \\
\hline Product & 3.60 & 3.66 & 3.88 & 3.59 & 3.61 & 7.719 & 4 & 1.930 & 0.206 & 0.935 \\
\hline Price & 2.61 & 2.61 & 2.63 & 2.56 & 2.64 & 21.690 & 4 & 5.423 & 0.505 & 0.732 \\
\hline Promotion & 2.49 & 2.50 & 2.75 & 2.47 & 2.48 & 37.080 & 4 & 9.270 & 0.775 & 0.542 \\
\hline Place/distrib'n & 3.38 & 3.42 & 3.44 & 3.45 & 3.34 & 42.671 & 4 & 10.668 & 0.956 & 0.431 \\
\hline
\end{tabular}

Key: $\mathrm{H}=$ Hitachi; $\mathrm{P}=$ Philips; $\mathrm{L}=\mathrm{LG} ; \mathrm{S}=$ Sharp.

Note 1: Wilkes' Lambda test for overall differences amongst means: $F=0.721$; $\operatorname{Sig}=0.775$.

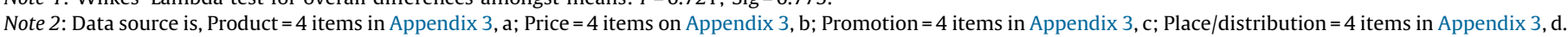


Table 5

ANOVA test for between brands and between categories differences.

\begin{tabular}{|c|c|c|c|c|c|c|c|c|c|}
\hline Brands under investigation & $N$ & Mean $^{a}$ & Std. Dev. & Between groups & Categories under investigation & $N$ & Mean $^{a}$ & Std. Dev. & Between groups \\
\hline Hitachi & 51 & 48.27 & 8.45 & $\mathrm{df}=4$ & Standardized & 198 & 48.24 & 7.895 & $\mathrm{df}=2$ \\
\hline 33 Other brands ${ }^{\mathrm{b}}$ & 191 & 48.24 & 7.889 & $F=0.30$ & & & & & $F=0.20$ \\
\hline Philips & 10 & 51.00 & 4.33 & $\operatorname{Sig}(p \leq 0.05)$ & Slightly adapted & 21 & 48.90 & 6.253 & $\operatorname{Sig}(p \leq 0.05)$ \\
\hline Sharp & 11 & 48.55 & 6.49 & $=0.88$ & & & & & $=0.82$ \\
\hline LG & 198 & 48.29 & 7.57 & & Adapted & 242 & 48.29 & 7.574 & \\
\hline
\end{tabular}

a Mean of 4 items $\times 4$ variables (product, price, promotions, place/distribution) $\times 5$-point Likert scale.

b Imported products. There is no Local Agency in the Libyan market.

Table 6

Multinomial logistic regression: parameter estimates - brand/level of adaptation vs marketing mix element.

\begin{tabular}{|c|c|c|c|c|c|c|c|}
\hline Brand $^{\mathrm{a}}$ & Marketing mix element & $B$ & Std. error & Wald & $\mathrm{df}$ & Sig & $\operatorname{Exp}(B)(95 \%$ Conf. Int.) \\
\hline \multirow[t]{5}{*}{ Philips } & Intercept & -3.833 & 2.633 & 1.650 & 1 & 0.199 & \\
\hline & Product & 0.078 & 0.130 & 0.358 & 1 & 0.549 & $1.08(0.84-1.40)$ \\
\hline & Price & -0.144 & 0.110 & 1.723 & 1 & 0.189 & $0.87(0.70-1.07)$ \\
\hline & Promotion & 0.184 & 0.098 & 3.511 & 1 & 0.061 & $1.20(0.99-1.46)$ \\
\hline & Place & 0.005 & 0.114 & 0.002 & 1 & 0.965 & $1.01(0.80-1.26)$ \\
\hline \multirow[t]{5}{*}{ LG } & Intercept & 1.649 & 1.084 & 2.314 & 1 & 0.128 & \\
\hline & Product & -0.026 & 0.055 & 0.219 & 1 & 0.640 & $0.98(0.88-1.09)$ \\
\hline & Price & -0.039 & 0.050 & 0.625 & 1 & 0.429 & $0.96(0.87-1.06)$ \\
\hline & Promotion & 0.010 & 0.047 & 0.044 & 1 & 0.833 & $1.01(0.92-1.11)$ \\
\hline & Place & 0.028 & 0.050 & 0.319 & 1 & 0.572 & $1.03(0.93-1.14)$ \\
\hline \multirow[t]{5}{*}{ Hitachi } & Intercept & -1.176 & 2.254 & 0.274 & 1 & 0.602 & \\
\hline & Product & -0.004 & 0.115 & 0.001 & 1 & 0.976 & $1.00(0.80-1.25)$ \\
\hline & Price & -0.012 & 0.105 & 0.012 & 1 & 0.912 & $0.99(0.81-1.21)$ \\
\hline & Promotion & 0.007 & 0.099 & 0.006 & 1 & 0.940 & $1.01(0.83-1.22)$ \\
\hline & Place & -0.019 & 0.104 & 0.034 & 1 & 0.854 & $0.98(0.80-1.20)$ \\
\hline \multirow[t]{5}{*}{ Other brands } & Intercept & 1.726 & 1.084 & 2.537 & 1 & 0.111 & \\
\hline & Product & 0.013 & 0.055 & 0.054 & 1 & 0.817 & $1.01(0.91-1.13)$ \\
\hline & Price & -0.006 & 0.050 & 0.015 & 1 & 0.903 & $0.99(0.90-1.10)$ \\
\hline & Promotion & 0.002 & 0.047 & 0.002 & 1 & 0.964 & $1.00(0.91-1.10)$ \\
\hline & Place & -0.019 & 0.050 & 0.679 & 1 & 0.410 & $0.96(0.97-1.06)$ \\
\hline $\begin{array}{l}\text { Adaptation }{ }^{\mathrm{b}} \\
\text { category }\end{array}$ & Marketing mix element & $B$ & Std. error & Wald & df & Sig. & $\operatorname{Exp}(B)(95 \%$ Conf. Int.) \\
\hline \multirow[t]{5}{*}{ Standardized } & Intercept & 0.311 & 0.649 & 0.230 & 1 & 0.632 & \\
\hline & Product & 0.037 & 0.033 & 1.293 & 1 & 0.256 & $1.04(0.97-1.11)$ \\
\hline & Price & 0.031 & 0.030 & 1.023 & 1 & 0.312 & $1.03(0.97-1.09)$ \\
\hline & Promotion & -0.013 & 0.029 & 0.207 & 1 & 0.649 & $0.99(0.93-1.04)$ \\
\hline & Place & -0.058 & 0.030 & 3.601 & 1 & 0.058 & $0.94(0.89-1.00)$ \\
\hline \multirow{5}{*}{$\begin{array}{l}\text { Slightly } \\
\text { adapted }\end{array}$} & Intercept & -4.404 & 2.858 & 2.374 & 1 & 0.123 & \\
\hline & Product & 0.126 & 0.145 & 0.748 & 1 & 0.387 & $1.134(0.85-1.51)$ \\
\hline & Price & 0.096 & 0.122 & 0.619 & 1 & 0.431 & $0.91(0.72-1.15)$ \\
\hline & Promotion & 0.145 & 0.107 & 1.839 & 1 & 0.175 & $1.16(0.94-1.42)$ \\
\hline & Place & -0.103 & 0.119 & 0.749 & 1 & 0.387 & $(0.71-1.14)$ \\
\hline
\end{tabular}

a Reference category is Sharp.

b Reference category is 'Adapted'.

The Wald criterion was not significant for any of the evaluated relationships, and $\operatorname{Exp}(B)$ fell consistently within the 95\% confidence interval, results implying that attitude toward the 4Ps did not predict attitude toward adaptation category and, by implication, vice versa. Overall, therefore, combining results from MANOVA (Table 4), ANOVA (Table 5) and logistic regression (Table 6) tests it was determined that customer attitude toward marketing programs, in relation to their preferred brand, was not significantly impacted by level of adaptation. In other words, the results demonstrate that an adapted brand does not engender a higher relative attitude amongst its adherents than does a nonadapted brand amongst its adherents. Thus, if a customer likes a brand, he/she likes that brand; and doesn't necessarily like it more just because it is adapted (or less, because it is not).

\subsubsection{Results - Brand preference and $C O B$}

Investigations into brand preference (upper section, Table 7) suggested LG was far and away the most popular. Its market position is exceptional - approximately four-times more popular (32.5\%) than each of their closest rivals, Hitachi (8.7\%) and Daewoo (8.2\%). LG has been operating at some level within the Libyan market for more than 15 years now, much longer than other Asian brands considered, and this will likely have contributed to its market-sensing capability, contributing both to relative sales success and to a relatively highly developed strategic approach (see Table 2: both 'marketing research' and 'marketing control' are more adapted than for competitors). Philips offers an interesting contrast in that they have also operated in Libya for many years, but evidence (at 1.6\%) comparatively low market share. They have, however, focused largely on lighting products and only recently expanded into major appliances; perhaps, though, not drawing heavily from past experiences.

The lower section of Table 7 shows major appliance preferences organized on the basis of COB and, considering the order of brands in the top section, it is not surprising to see South Korea (42.3\%) and Japan (23\%) head the list - and by a considerable 
Table 7

Major appliances, brand and country-of-origin brand (COB) - recently purchased or purchase imminent.

\begin{tabular}{|c|c|c|}
\hline $\begin{array}{l}\text { Brand recently purchased or purchase } \\
\text { imminent (Preferred brand) }\end{array}$ & Quantity & $\%$ \\
\hline LG & 198 & 32.5 \\
\hline Hitachi & 53 & 8.7 \\
\hline Daewoo $^{a}$ & 50 & 8.2 \\
\hline $\mathrm{JVC}^{\mathrm{a}}$ & 29 & 4.8 \\
\hline Sony ${ }^{\mathrm{a}}$ & 26 & 4.3 \\
\hline Brand not reported & 148 & 24.3 \\
\hline \multirow[t]{2}{*}{32 different brands ${ }^{b}$} & 105 & 17.2 \\
\hline & 609 & .0 \\
\hline Country of origin of Brand (COB) & Quantity & $\%$ \\
\hline South Korea & 258 & 42.4 \\
\hline Japan & 140 & 23.0 \\
\hline Arab/Muslim countries & 13 & 2.1 \\
\hline Netherlands & 10 & 1.6 \\
\hline USA & 8 & 1.3 \\
\hline Italy & 6 & 1.0 \\
\hline Germany & 3 & 0.5 \\
\hline Not known ${ }^{\mathrm{c}}$ & 148 & 24.3 \\
\hline \multirow[t]{2}{*}{8 other countries } & 23 & 1.5 \\
\hline & 609 & .0 \\
\hline
\end{tabular}

a Imported products. There is no Local Agency in the Libyan market.

b Imported products + Sharp $(11=1.8 \%)$ and Philips $(10=1.6 \%)$.

c Brand not reported, hence country-of-origin not known.

margin. Arab/Muslim COBs (Libya, Egypt and Turkey are listed collectively to illustrate both presence and relative lack of individual significance to the market). The Netherlands is listed fourth and the USA fifth, though at less than $2 \%$ each it can be seen that the difference between West and East is substantial.

From a country image perspective (see Table 8) COB purchasing preferences were substantially at odds with consumer perspectives on COB, and although South Korean brands (primarily LG and Daewoo) represented approximately $40 \%$ of all sales, South Korea

Table 8

Major appliances - country image perceptions in the Libyan market.

\begin{tabular}{|c|c|c|}
\hline $\begin{array}{l}\text { Appliances from the following countries } \\
\text { are technologically superior }\end{array}$ & Quantity & $\%$ \\
\hline Japan & 226 & 37.10 \\
\hline USA & 160 & 26.30 \\
\hline Italy & 149 & 24.50 \\
\hline South Korea & 21 & 3.40 \\
\hline Germany & 22 & 3.60 \\
\hline \multirow[t]{2}{*}{ 11other countries } & 31 & 5.10 \\
\hline & 609 & 1000 \\
\hline $\begin{array}{l}\text { Appliances from the following } \\
\text { countries are prestigious }\end{array}$ & Quantity & $\%$ \\
\hline USA & 284 & 46.60 \\
\hline Italy & 176 & 28.90 \\
\hline Japan & 75 & 12.30 \\
\hline Netherlands & 18 & 3.00 \\
\hline South Korea & 9 & 1.50 \\
\hline \multirow[t]{2}{*}{13 other countries } & 47 & 7.70 \\
\hline & 609 & 1000 \\
\hline $\begin{array}{l}\text { Given a free choice, I would prefer to buy } \\
\text { appliances from the following countries }\end{array}$ & Quantity & $\%$ \\
\hline Japan & 233 & 38.30 \\
\hline Italy & 174 & 28.60 \\
\hline USA & 144 & 23.70 \\
\hline Germany & 20 & 3.20 \\
\hline South Korea/Netherlands & 11 & 1.80 \\
\hline \multirow[t]{2}{*}{12 other countries } & 27 & 4.4 \\
\hline & 609 & 1000 \\
\hline
\end{tabular}

itself was not perceived as auspicious. Japan's notability on both lists is perhaps both predictable and understandable, though the presence of the USA on the three 'desired' lists is of particular interest, given that 'preferred brand' incidences are low.

\subsubsection{Results - Reasons for product preference}

The final research question concerns those criteria informing consumers' final purchase decisions. Marketing programs are designed to impact all stages of consumer concern and the latter stages of C. P. Russell's ubiquitous AIDA model (Grzybek, 2012) desire and action - were determined as being impacted by a combination of $\mathrm{COB}$, brand name, safety, price, salesperson's advice, and 'up-to-date-ness' of the product itself (collectively perhaps analogous to Roth's, 1995, notion of 'brand image' rather than the simpler 'product identity' concept alluded to earlier) - and of particular interest was the relative importance of $\mathrm{COB}$ to the decision making process.

Table 9 is a contingency table cross-tabulating \#1 purchase criteria choices and preferred COBs (see Table 7). From here it can be detected that, generally, both $\mathrm{COB}$ and product safety concern consumers most ( $41.2 \%$ and $44.3 \%$ of the total, respectively), whilst further analysis shows that $46 \%$ of all consumers placed COB in their top three choices - even though, at $12.3 \%$, safety + brand name +latest product was, paradoxically, the most frequently occurring choice cluster. Brand name is clearly not unimportant (9.2\%), and it is likely that this, plus perceived COB and safety, are substantially associated within the consumers' mind (Essoussi \& Merunka, 2007; Knight, 1999), and that these collectively represent the key, and final, factors determining which brand/product a consumer buys.

Different consumers, though, will prioritize these differently, and it is interesting to note that there is some variety in the choice profiles between COB's concerned, with those consumers preferring South Korean and USA brands focusing on safety first and on COB second, whilst for consumers buying Japanese brands the situation is reversed. A Chi-squared test comparing choice profiles for Japan and South Korea (a comparison of particular interest given geographical proximity and relative status on Table 8 ), however, suggested no significant difference $\left(X^{2}=6.592, \mathrm{df}=5, p=0.253\right)$, so similarity of the two sets of data could not be disproved. Implications of this, and other findings, are detailed below.

\section{Discussion}

This research contributes to existing knowledge on overseas marketing program decision-making and its effect by empirically investigating the nature and impact of marketing practices on one important product category, major appliances, in a single, evolving, Arab market. It provides insight into how both adaptation/ standardization and country-of-origin influences consumers in a politically sensitive region and, given the relative homogeneity of the Arab world (Hofstede, 2012; Mahajan, 2013) some results may be generalizable to the region. The study, atypically, addresses both sides of the customer/supplier divide and is, it is believed, the first to explore these issues in Libya whilst, coincidentally, being one of few studies in the field of marketing, per se, conducted there. The study focused upon four primary research questions (see Section 1), for each of which a series of propositions is suggested all developed from the broader international literature for testing in the study-specific context.

Firstly standardization/adaptation strategies adopted for Libya by locally active major appliance brands were investigated. It was found that strategies varied, with LG pursuing a broadly adaptation-based philosophy and, by contrast, Sharp adopting an almost totally standardized approach. Philips and Hitachi both made concessions to local circumstance but LG was unique in its broad commitment to the market. The consensus was largely for 
Table 9

Contingency table - actual country of origin, brand (COB) and consumer purchasing criterion.

\begin{tabular}{|c|c|c|c|c|c|c|c|c|}
\hline \multirow[t]{2}{*}{ Actual $\mathrm{COB}$} & \multirow[t]{2}{*}{ Characteristic } & \multicolumn{7}{|c|}{ \#1 Purchasing criterion } \\
\hline & & $\mathrm{COB}$ & Safety & Price & Brand name & Latest product & Sales-person advice & Totals \\
\hline \multirow[t]{3}{*}{ South Korea } & Count \#1 in Criterion & 99 & 120 & 5 & 24 & 3 & 4 & 288 \\
\hline & $\% \# 1$ in Actual COB & 38.8 & 47.1 & 2.0 & 9.4 & 1.2 & 1.6 & $100 \%$ \\
\hline & \% In Criterion Count & 56.9 & 64.2 & 50.0 & 61.5 & 100 & 44.4 & \\
\hline \multirow[t]{3}{*}{ Japan } & Count \#1 in Criterion & 62 & 51 & 4 & 14 & 1 & 5 & 137 \\
\hline & $\% \# 1$ in Actual COB & 45.6 & 37.5 & 2.9 & 10.3 & 0 & 3.7 & $100 \%$ \\
\hline & \% In Criterion Count & 37.9 & 26.6 & 40.0 & 35.9 & 0 & 55.6 & - \\
\hline \multirow[t]{3}{*}{ Arab/Muslim } & Count \#1 in Criterion & 6 & 6 & 0 & 1 & 0 & 0 & 13 \\
\hline & $\%$ \#1 in Actual COB & 46.2 & 46.2 & 0 & 7.7 & 0 & 0 & $100 \%$ \\
\hline & \% In Criterion Count & 3.5 & 3.2 & 0 & 2.6 & 0 & 0 & - \\
\hline \multirow[t]{3}{*}{ Netherlands } & Count \#1 in Criterion & 5 & 5 & 0 & 0 & 0 & 0 & 10 \\
\hline & $\% \# 1$ in Actual COB & 50.0 & 50.0 & 0 & 0 & 0 & 0 & $100 \%$ \\
\hline & \% In Criterion Count & 2.9 & 2.8 & 0 & 0 & 0 & 0 & - \\
\hline \multirow[t]{3}{*}{ USA } & Count \#1 in Criterion & 2 & 5 & 1 & 0 & 0 & 0 & 8 \\
\hline & $\%$ \#1 in Actual COB & 25.0 & 62.5 & 12.5 & 0 & 0 & 0 & $100 \%$ \\
\hline & \% In Criterion Count & 1.2 & 2.8 & 10.0 & 0 & 0 & 0 & - \\
\hline \multirow[t]{3}{*}{ All } & Count \#1 in Criterion & 174 & 187 & 10 & 39 & 3 & 9 & 422 \\
\hline & $\%$ \#1 in Criterion & $41.2 \%$ & 44.3 & 2.4 & 9.2 & 0.7 & 2.1 & $100 \%$ \\
\hline & \% In Criterion Count & $100 \%$ & $100 \%$ & $100 \%$ & $100 \%$ & $100 \%$ & $100 \%$ & - \\
\hline
\end{tabular}

standardized brand name and product design/packaging but modified distribution, broadly confirming similar findings in both Zou and Cavusgil (2002) and Powers and Loyka (2007, 2010) - who suggested adaptation priorities of distribution, price, promotions and, lastly, product to be the norm. Interestingly, though, both LG and Sharp did adapt the product slightly and clearly believed it important to address local circumstances. Neither, though, offered a complete new design.

Overall, results implied that brands concerned, generally, conform to a normative perspective whereby, in potentially challenging non-home markets, product, promotion and pricing are most likely to be centrally controlled whilst constraints on place/distribution will be eased in recognition of local contingency (Rafiq \& Ahmed, 1995; Theodosiou \& Leonidou, 2003). This would appear to support proposition P1a; that is, that the nature of marketing program adaptation is a function of the nature of the market, and that MNEs, generally, recognize and respond accordingly. This same conclusion was reached by both Katsikeas, Samiee, and Theodosiou (2006) and Kustin (2010) but, interestingly, they further suggested that degree, or extent of marketing program intervention might also be a function of nationally determined habit (e.g. Japanese firms are more inclined to adapt than those from the USA and Germany). Whether this is a primary determinant of international strategy, or whether other over-arching factors such as organizational culture or financial imperative was not evaluated, but the finding that extent of adaptation appeared more brand-specific than market-specific meant that evidence in support of proposition P1b was largely absent.

Factors influencing the standardization/adaptation strategies of the four brands considered was, though, the second research question pursued, although, of course, without extensive access to the brands concerned, obtaining evidence on the impact of cultural and financial brand characteristics was not possible. Instead we focused on two overtly evident issues common to all four brands (mode of entry and product category) and two issues that could be brand specific and that were pertinent to local endeavor (competitive awareness and HQ-subsidiary relationship). The mode of entry for all studied suppliers (Local Agency) generally involves the lowest degree of external involvement at local level. The four brands with a physical presence had, thus, all selected a means of market engagement that optimized balance between operational risk and local advantage. There was clearly an attempt here to close down cultural (Drogendijk \& Slangen, 2006) and/or psychic (Stottinger \& Schlegelmilch, 1998) distance and to maximize access to local resource/expertise whilst, coincidentally, maintaining optimal presence. Results indicated that, for consumer attitude, this paid dividends - given that for Distribution/Place imported brands performed relatively less well than those with local agencies. It should be noted, though, that for LG the local agency was more engaged than for other locally represented brands and that operations were considerably more developed. Results suggested that for this product category utility represented the major argument for offering standardized products (Jain, 1989) and though, clearly, it was not possible to compare with other categories of good, the nature of the product itself appeared to be one of the key determining characteristics for relevant decisions, confirming the conventional wisdom (see Birnik \& Bowman, 2007; Jain, 1989; Kotler, 2005; Viswanathan \& Dickson, 2007). Propositions P2a and P2b appear, therefore, largely uncontested.

It is believed, though, that the nature and length of the subsidiary/parent relationship was also a factor here (Rahman \& Bhattacharyya, 2003, for example, discuss the idea of 'first mover advantage', whilst Alpert et al., 2001 discuss benefits obtained by 'pioneer' brands) and it was clear that a well-established and substantive partnership was of benefit, potentially favoring both Philips and LG. It was also apparent that although degree of competition impacted the decision to standardize/adapt could not be determined (all four companies faced the same competitive context) awareness of the range and nature of that competition did (see, also, Birnik \& Bowman, 2007). It was noted earlier that LG's products were adapted most, and this can perhaps be partially ascribed to its wider focus and differing view as to what represents competition. Jain (1989) suggested that lower levels of competition were likely to result in less adaptation and LG's more proactive approach appears, thus, to suggest an absence of complacency contrasting, perhaps, with wider evidence of a tendency for globalizing companies to suffer initiative fatigue over time (Hallbäck \& Gabrielsson, 2013). It should be noted, too, that although there is a body of evidence suggesting marketing mix standardization can impact financial performance favorably (e.g. Calantone et al., 2004; Kustin, 2010), both Katsikeas et al. (2006) and Schmid \& Kotulla (2011) note that superior financial performance in global markets can be influenced by a range of factors, and that the success of a given market strategy is 
conditional upon alignment between it and key contextual factors, implying a one-size-fits-all model cannot be assumed. Propositions P2c and P2d, therefore, are also supported, with the case of LG offered as especially strong evidence of a brand using competitive awareness and a strong local relationship to guide, and help advance, coincidentally a more prominent and effective adaptation strategy.

From a holistic perspective, the standardization vs adaptation debate (see, for example, Schmid \& Kotulla, 2011; Tan \& Sousa, 2013) has proved to be both enduring and inconclusive. This is because broader arguments focus on both cost and benefit - and because multiple factors of both are considered, it is frequently difficult to disentangle the evidence. This present study adopts a more selective approach and, via the third of four research questions, aims to assess consumer brand response in respect of attitude to the $4 \mathrm{P}$ marketing mix and, also, relative brand preference. Relevant propositions presume a positive relationship between degree/extent of adaptation and each of these response characteristics.

For the first of these the investigation sought to explore associations via a range of statistical tests focused variously on marketing mix elements (collectively and individually) and brand name, with adaptation/standardization category as independent variable. Here differences in attitude toward marketing mix elements was observed, with 'product' and 'place' faring best, and 'price' and, and especially, 'promotions' least well. Given wideranging customer suspicion concerning that most overt form of promotion, advertising (e.g. Darke \& Ritchie, 2007; Lysonski, Durvasula, \& Watson, 2003), this is not surprising, especially noting that, traditionally, overseas suppliers have consistently failed to adjust to the cultural distinctiveness of Arab/Muslim consumers (Marinov, 2007) yet, as Mostafa (2011) points out, this is unwise. In the most widely cited study in this area (Gaski \& Etzel, 2005, in the USA), a similar pattern was found, though the relative positions of price and promotions were reversed. A related investigation in Turkey (Peterson \& Ekici, 2007), Libya's close, but more Westernized, neighbor closely mirrored these results, contrasting with Mady, Cherrier, Lee, and Rahman (2011) who uncovered evidence of positivity toward advertising in Dubai; suggesting, perhaps, some intra-regional variety dependent upon relative materialistic development. Of main concern here, though, was to seek evidence regarding standardization/adaptation strategy, and for attitude toward individual elements of the 4Ps no significant difference between differently strategized appeared to exist.

To further inform an understanding of the relationship between brands, adaptation/standardization strategy, and strength/direction of attitude toward the marketing mix, survey results from customers of 33 other standardized brands were also incorporated into the dataset, thus creating a more numerically robust category. Subsequent tests for differences between brands and between adaptation/standardization categories in respect of attitude toward the 4Ps provided no evidence of distinction, and the final associative test, using logistic regression to determine the extent to which attitude toward one or all of the marketing mix elements might predict attitude toward brand and/or adaptation/standardization category again failed to suggest that, for this category of goods, in this part of the world, a discernible relationship existed. Consequently, proposition P3a was not supported.

The most adapted brand (LG) was also recognized as the most preferred brand, so some evidence in support of P3b, however, was observed. However, Hitachi - the least adapted of the four studyspecific brands - and other brands operating on an import, rather than local agency, basis were preferred more than the two 'slightly adapted' brands included in the study (Hitachi and Philips), so there was clearly no evidence of a direct and linear relationship conjoining degree/extent of adaptation and recent and/or likelihood of purchase. Accommodating customer needs, desires and expectations in pursuit of profit is, of course, one of the primary objectives for marketing mix adaptation (e.g. Lages, Abrantes, \& Lages, 2008) and there is a continuum that relates to this rather than a choice between absolutes (Vrontis et al., 2009). It is possible, therefore, that for customers to be substantively persuaded to buy, some sort of tipping point (Gladwell, 2001) or critical mass is required, and that a 'slight' effort at adaptation is no more convincing for consumers than no adaptation at all. There is, though, evidence now mounting that LG's endeavors are more significant over a range of market-focused characteristics: not only marketing mix adaptation, but also competitive awareness, HQ-subsidiary relationship, and trading longevity. Thus, marketing mix adaptation, perhaps beyond some tipping point, but more likely as part of a wider market-focused approach (e.g. Navarro, Losada, Ruzo, \& Díez, 2010; Zou \& Cavusgil, 2002), appears to attract more consumers (thus partially supporting proposition P3b) but does not make those choosing an adapted brand like it more. This, it is believed, is a significant finding, and suggests that - certainly in the market assessed - brand reach and brand adherence are not necessarily related.

The last of the four research questions assessed related to country-of-origin, defined specifically as country-of-origin, brand ( $\mathrm{COB}$ ). As there was no significant difference between brands in respect of consumer attitude to marketing mix, then proposition P4a must immediately be rejected; preference for COB did vary, but attitude toward marketing mix did not. The most frequently purchased brands in Libya emanate from South Korea but there was a relatively limited level of popular regard for the country itself (thus questioning the validity of proposition $\mathrm{P} 4 \mathrm{~b}$ ), and this contrasted sharply with profiles for Japan and the USA, both of which had also fared well in other studies (e.g. Rosenbloom \& Haefner, 2009). Japanese brand sales were healthy, and this largely corresponded to the regard with which the country was held, but for the USA and Korea sales and esteem were negatively associated, albeit in different directions.

The USA case is especially interesting given the populist assumption that anti-American sentiment is rife within Arab regions (e.g. Katzenstein \& Keohane, 2007). Both external agencies (US \& FCS, 2006) and local agents (for Sharp and Hitachi) report that Libyan consumers regard American brands to be superior, even if other factors (e.g. price, availability and at least some structural COB resistance) will undoubtedly inhibit sales, and the 'decisions criteria' evidence - albeit slight, given the low representation of USA in the data, implies a reputation for safe/high quality products. According to Vigneron and Johnson (1999) prestige is often derived from perceptions regarding technical superiority/quality, and earlier (pre-embargo) experiences may well account for some of the regard in which the USA is held. Souiden (2002) also suggests that Arab consumers have a broad preference for USA products and further analysis showed that most (approximately 80\%) of consumers reporting positively here were in the 18-37 years age group, implying a degree of generational partiality unlikely to be based upon experience alone. Whether this means that, at a popular level, perceptions of anti-US sentiment are misguided; or whether it means Libyan consumers can dispassionately, and paradoxically, separate the political from the utilitarian is unclear, but it does imply that market research may well be a useful and viable adjunct to other more conventional means of reading the state of a nation, or region, and that consumption (either actual or desired) can be regarded as a force for, or predictor/indicator of, change.

Observations concerning South Korea suggest a different though equally intriguing conundrum. The low regard in which 
South Korea is held is evidence of a relatively negative COB profile (Kotler \& Gertner, 2002), and it is notable that of all the successful East Asian economies only Japan appears in the top ten international 'country as brand' league table (Branding Korea, 2012). Despite this, sales for South Korean major appliances, and for LG particularly are, paradoxically, substantial, and it would not be inappropriate to explore both brand and COB together.

LG is clearly the most successful major appliance brand in Libya. The brand adapts its marketing mix more than any other, but it has been demonstrated that consumers preferring an adapted brand do not appear to have a more positive attitude toward that brand's marketing mix than do those preferring any other. Taken together, these observations imply that although higher levels of marketing mix adaptation may perhaps contribute to the achievement of greater market share, this is unlikely to result in increased depth of commitment from the consumer. This may further imply that market share is not only hard won, but also precariously sustained, and that international success is more a function of strategic, rather tactical, dedication.

Further, despite COB being a significant consumer choice determinant, South Korea itself is far from well-regarded and, from this perspective, LG should have been at a distinct competitive disadvantage. It has also been demonstrated, though, that paradoxically - those consumers buying South Korean brands place $\mathrm{COB}$ high on their list of decision criteria, and this appears to further deepen the paradox, implying too - as with proposition $\mathrm{P} 4 \mathrm{~b}$ - that proposition P4c cannot be supported. Wider research, though, reveals some interesting points. According to Navarro et al. (2010), the more an organization commits to a market the more it is willing to adapt. Localization, to an extent appropriate to the context and the circumstances, is a broad strategic preference for LG (Cheng, Blankson, Wu, \& Chen, 2005; Park, Shintaku, \& Amano, 2010) and this can range from product/range development for a specific market (Banerjee, 2007) to a minor tactical 'tweak'. They are known to have an intrepid and proactive globalizing strategy (Cheng et al., 2005) and, according to Hiraga (2010), this is characterized by a 'prompt and bold' commitment to new market expansion - even in the face of adverse conditions/infrastructures - and to long-term planning that incorporates/encourages local decision making which, in turn, is likely to be facilitated by strong support from LG headquarters (Lee \& MacMillan, 2008). The evidence from interviews with local LG representatives bears witness to the development of a robust, highly enterprising and fully supported local marketing strategy that contrasts sharply with the relatively indifferent and apparently timid approach of other brands.

Dinnie (2009), asserts, though, that Korean companies purposefully downplay their origins, partly because consumers traditionally expect goods of Korean origin to be cheap (the 'Korean discount' - due mainly to an early reputation for poor quality), and also partly because of the 'North Korea effect' (for some, North and South are indistinguishable). Ironically, results indicate that the brand appears to have a reputation for good quality (safe products) but because identity is traditionally suppressed this has not impacted positively on COB perspectives and, according to Magnusson et al. (2011) it is not unusual for consumers to assume that Korean brands are, in fact, Japanese brands - an impression that South Korean firms, thus far, have not sought to dispel. This would appear to suggest that, rather than using the term "brands associated with that country" in propositions $\mathrm{P} 4 \mathrm{~b}$ and $\mathrm{P} 4 \mathrm{c}$ it might have been more appropriate to state "brands believed to be associated with country"; under which circumstances it might be possible to conclude that both are supported.

\section{Conclusions and managerial implications}

This study set out to explore four research questions, all focused on MNEs and the general issue of 'doing business in Libya'. For the first (Q1. The nature and extent of adaptation) it was concluded that, broadly speaking, all four of the considered MNEs recognized the marketing mix standardization/adaptation priorities relevant to entry into a challenging market (in this case Libya) but, by contrast, practiced adaptation to different degrees, with LG the only brand recognized as 'adapted' (other categories being 'not adapted' and 'slightly adapted'). For the second (Q2. Factors influencing standardization/adaptation choices) the study concluded that for all four considered brands, both mode of entry and product category were key factors influencing tactical approaches to standardization/adaptation, but that only LG had focused sufficiently on local competition and local dealer relationships to the extent that these, too, substantively impacted decisions on the locally applied marketing mix.

For research question 3 (Q3. Libyan consumer attitudes toward program standardization/adaptation decisions) it was found that the most adapted brand (LG) was the most 'preferred' large domestic appliance brand in Libya (i.e. the largest proportion of consumers stated they had bought, or intended to buy, its products) but - perhaps unexpectedly - no discernible relationship existed between extent of adaptation and attitude to brand marketing mix. This suggested that although LG was the most successful of the brands operating in Libya, brand reach and brand adherence were not necessarily related. And for research question 4 (Q4. Effects of brand name and $\mathrm{COB}$ ) it was concluded that although LG was the most preferred brand in Libya this was not related to its association with headquarters location, South Korea. In fact, further research suggested that LG was succeeding in spite of its brand country-of-origin, and that part of its success might be attributed to its perceived association with Japan. Libyan consumer behavior, therefore, was likely influenced by perceptions of country image, but consumer knowledge regarding brand origins was perhaps less than well developed.

What do these outcomes suggest, therefore, in terms of MNE approaches to the Libyan market and of the behavior/reaction of Libyan consumers? To understand this best it would perhaps be appropriate to focus first on LG, demonstrated as the most effective of brands in the Libyan market. By considering a combination of all four research questions, the study concludes that it is understanding and confronting the market (which will likely involve, but not depend upon, adapting for the market) that has brought the greatest rewards, and that by adopting a highly proactive and insistent approach to overseas market management LG is benefiting accordingly.

LG have operated longest in Libya and have taken the time to build local relationships, to evaluate all aspects of the market, and to commit - in all manner of ways - to that market. This suggests, perhaps, that though the adaptation/standardization issue is of interest, its role remains primarily tactical, and that the real debate should focus more on the wider strategic context (e.g. Navarro et al., 2010; Zou \& Cavusgil, 2002), and on strategy/context fit (Theodosiou \& Leonidou, 2003) and, thus, on the culture of the globalizer as much as that of the globalized. Both existing and potential suppliers to the region should note that, according to this present study, extensive and sustainable sales are not won easily, and that an approach that is coincidentally bold, long-term oriented and, especially, committed, is necessary for success. Having an advanced understanding of how both brand and COB are coincidentally perceived, and carefully managing and monitoring perceptions, appears also to be of importance. Further, although marketing mix adaptation may well help support and complement other determinants of market share, this does not appear to have a significantly differentiating impact on relative consumer attitude which, on the basis of this study, remains constant irrespective of the general level of standardization/adaptation adopted. 
Whether these observations are specific to the Libyan, and/or wider Arab, market is less easy to speculate on authoritatively, as our study is case-based rather than comparative. The Libyan people are though, according the Hofstede Center (2014), high on both power distance and uncertainty avoidance factors, and low on pragmatism, indulgence and individuality, and although the Hofstede system is occasionally contested for its over-simplification (e.g. Venaik \& Brewer, 2013), this marks out Libya as being typical, also, of what Hall (1976) called a 'high context' culture, the key characteristics of which are a focus on long-term relationships, a tendency for building social/communication boundaries, and a proneness to internalized understandings; meaning that associated markets are likely to be difficult to penetrate, with development requiring both patience and commitment. According to Hiraga (2010), selection of growth markets based on long-range plans and local relationships is one of the key features of LG's global strategy, and this present study appears to confirm both the idealized nature of the Libyan market and LG's predisposition and ability to exploit it. As a further point, the study also found that Libyan consumers do not appear to be politically biased in terms of their domestic appliance preferences, a point of especial interest, clearly, to potential suppliers with expansionist ambitions.

\section{Limitations and directions for further research}

There are, clearly, limitations to this research. The relatively small number of locally active overseas manufacturers in Libya means the range of data obtained was necessarily constrained. This was known at the outset but it was not apparent at that stage how this might impact data depth. Further, for two brands actual/ intended sales were relatively low and the range of standardization/adaptation difference across all brands was not as wide as would have been preferred. Consequently, empirical results must be considered tentative. It is also acknowledged that assuming the marketing mix in respect of the thirty three 'other brands' was standardized was reasonable rather than verified, and that related results should be considered accordingly.

Methods were largely exploratory but also quantitative and systematic - but this, inevitably, impacted the richness of the data. Although not reported in this paper, free text responses from local agency managers provided limited but occasionally revealing insights into the relationships that existing between major suppliers and those co-opted to work on their behalf. International marketing research to date has largely considered the extent to which overseas suppliers understand, recognize and exploit local consumer behavior; but in a global market where international uncertainty and increased potential for expansion coincide, developing a deeper and better understanding of local business environments, and how this can best be exploited, will be equally relevant (see, for example, Yildiz \& Fey, 2012), and not least in Arab markets (Khakhar \& Rammal, 2013). A qualitative approach to addressing both agency and supplier concerns at local level would help provide insights on this increasingly important issue.

Similarly, a number of the points raised - especially in respect of apparently paradoxical consumer responses to, and influence of, country-of-origin effect - would benefit from further deductive research. Both the development of South Korea's evolving country-as-brand status, and also the tensions inherent in markets where materialistic aspiration and political allegiance (either imposed or real) might be in conflict, are considered to be worthy of further research. The study has not sought to disentangle adaptation effect, the impact of long-term/deep commitment to a market, and influence of COB; but all are clearly relevant and likely interrelated, and further work exploring the nature of such relationships in a Libyan context would clearly be useful. The country's considerable GDP ( $\$ 87.91$ billion in 2011); its strategic location as gateway to major developing markets in both the Middle East and the African continent; and its rapidly developing commercial infrastructure (Ministry of Economy, 2013), imply that the pursuit of further understanding should be an imperative for researchers worldwide.

\section{Appendix 1. Interview schedule and item sources: classification criteria}

\begin{tabular}{|c|c|c|}
\hline Research construct & Measure & Source \\
\hline $\begin{array}{l}\text { 1. Classification of the } \\
\text { standardization } \\
\text { levels of marketing } \\
\text { programs }\end{array}$ & $\begin{array}{l}\text { (a) Marketing Research } \\
\text { - Do you use readily available marketing information relating to Libyan consumers? } \\
\text { - Do you conduct market surveys/research on Libyan consumers? } \\
\text { (b) Pricing } \\
\text { - Do you adapt discount levels to accommodate the Libyan Market? } \\
\text { - Do you adapt prices to accommodate the Libyan Market? } \\
\text { (c) Promotion } \\
\text { - Do you adapt promotional campaigns to address the Libyan market? } \\
\text { - Do you adapt advertising messages to address the Libyan market? } \\
\text { (d) Distribution } \\
\text { - Do you adapt the flow and level of distribution activity to address Libyan consumer needs and requirements? } \\
\text { - Do you adapt your system of distribution to address Libyan consumer needs and requirements? } \\
\text { (e) Product decisions } \\
\text { - Do you adapt product packaging to meet Libyan consumer preferences? } \\
\text { - Do you adapt product features/specifications to meet Libyan consumer preferences? } \\
\text { (f) Marketing control } \\
\text { - Do you voluntarily collect Libyan consumer behavior/feedback data on behalf of the brand parent company's } \\
\text { marketing department? } \\
\text { - Does the brand parent company's marketing department request specific marketing reports/data in respect of } \\
\text { Libyan consumer behavior/feedback? } \\
\text { (g) Market comparison } \\
\text { Comparing the situation in Libya and in the brand parent company's home market, how similar or different are the } \\
\text { following marketing program elements for your major product(s)? } \\
\text { - Product (physical characteristics, brand name and packaging) } \\
\text { - Promotion (promotion, positioning, advertising theme, media allocation and advertising copy) } \\
\text { - Pricing policy (retail price, discounts, etc.) } \\
\text { - Distribution (including customer service and sales force function/role) }\end{array}$ & $\begin{array}{l}\text { (g) - Oszomer, } \\
\text { Bodur, and } \\
\text { Cavasgill (1991) } \\
\text { and Ozsomer and } \\
\text { Simonin (2004) }\end{array}$ \\
\hline
\end{tabular}




\section{Appendix 2. Interview schedule and item sources: decision factors}

\begin{tabular}{|c|c|c|}
\hline Research construct & Measure & Source \\
\hline $\begin{array}{l}\text { 2. Factors determining } \\
\text { the degree of } \\
\text { standardization } \\
\text { adopted }\end{array}$ & $\begin{array}{l}\text { (a) Product/packaging design } \\
\text { - Is the nature of your product(s) such that adaptation is essential for entering the Libyan market? } \\
\text { - Is it company policy to routinely develop national or regional product designs and/or marketing programs? } \\
\text { - Is it company policy to maintain universal brand names, packing, colors and so on? } \\
\text { (b) Mode-of-entry } \\
\text { - What is the exact nature of your parent company's mode of entry into the Libyan market (e.g. Branch Office, } \\
\text { Joint Venture/Joint Stock Company with a local firm, Representative Office, enter Libya under the provisions of } \\
\text { investment law and entering through Local Agency) } \\
\text { (c) Headquarters-subsidiary relationship } \\
\text { - Is there consensus between you (as a subsidiary) and the parent company in terms of standardization/ } \\
\text { adaptation strategy? } \\
\text { (d) Competition } \\
\text { What are the factors (from the choices below) that you take into account when developing marketing decisions/ } \\
\text { strategies? } \\
\text { - The marketing behaviors/activities of all companies offering similar products and services to Libyan } \\
\text { consumer at similar prices } \\
\text { - The marketing behaviors/activities for all companies offering home appliances in the Libyan market } \\
\text { The marketing behaviors/activities of all companies offering products that deliver the same/similar service. } \\
\text { - The marketing behaviors/activities of all companies that compete within the Libyan market }\end{array}$ & $\begin{array}{l}\text { Adapted from Jain } \\
\text { (1989), Kotler (1986) }\end{array}$ \\
\hline
\end{tabular}

\section{Appendix 3. Consumer survey and item/scale sources}

\begin{tabular}{|c|c|c|c|}
\hline Research variable & Items & Source & $\begin{array}{l}\text { Scale } \\
\text { reliability }\end{array}$ \\
\hline \multirow{5}{*}{$\begin{array}{l}\text { Consumers' responses } \\
\text { toward marketing } \\
\text { programs }\end{array}$} & $\begin{array}{l}\text { Note: Respondents were directed to react to the scales/items below - (a) to (e) - in } \\
\text { respect of their 'preferred' brand. }\end{array}$ & & \\
\hline & $\begin{array}{l}\text { (a) Product (Likert 5-point scale) } \\
\text { - The quality of most appliances is as good as can be expected. } \\
\text { - I am satisfied with most appliances. } \\
\text { - The quality of appliances has improved consistently over the years. } \\
\text { - Appliances generally have a good guarantee. }\end{array}$ & $\begin{array}{l}\text { Adapted from Dawar } \\
\text { and Parker (1994), } \\
\text { Teng, Laroche, and Zhu } \\
\text { (2007) }\end{array}$ & 0.78 \\
\hline & $\begin{array}{l}\text { (b) Price (Likert 5-point scale) } \\
\text { - The quality of most appliances is as good as can be expected. } \\
\text { - I am satisfied with most appliances. } \\
\text { - The quality of appliances has improved consistently over the years. } \\
\text { - Appliances generally have a good guarantee. }\end{array}$ & $\begin{array}{l}\text { Adapted from Dawar } \\
\text { and Parker (1994); } \\
\text { Gaski and Etzel (1986) }\end{array}$ & 0.76 \\
\hline & $\begin{array}{l}\text { (c) Promotion (Likert 5-point scale) } \\
\text { - I find most advertising to be very annoying. } \\
\text { - Most advertising makes false claims. } \\
\text { - I enjoy most of the advertisements I encounter. } \\
\text { - Most of the advertising I encounter fails to consider/recognize the values of } \\
\text { society at large }\end{array}$ & $\begin{array}{l}\text { Adapted from Gaski } \\
\text { and Etzel(1986), Hague } \\
\text { and Jackson (1992), } \\
\text { Teng et al. (2007) }\end{array}$ & 0.79 \\
\hline & $\begin{array}{l}\text { (d) Place/Distribution (Likert 5-point scale) } \\
\text { - Most suppliers serve their customers well. } \\
\text { - I find most salespeople to be very helpful. } \\
\text { - Most suppliers provide an adequate selection of goods. } \\
\text { - Most suppliers provide adequate service. }\end{array}$ & $\begin{array}{l}\text { Adapted from Dawar } \\
\text { and Parker (1994), } \\
\text { Gaski and Etzel (1986), } \\
\text { Teng et al. (2007) }\end{array}$ & 0.80 \\
\hline Country image & $\begin{array}{l}\text { Country image (Free choice) } \\
\text { - Appliances from following countries* are technologically superior } \\
\text { - Appliances from the following countrie* are prestigious } \\
\text { - Given a free choice, I would prefer to buy appliances from the following } \\
\text { countries* } \\
{ }^{*} \text { Respondents may list any country they feel to be appropriate }\end{array}$ & $\begin{array}{l}\text { Lundstrom, Lee, and } \\
\text { White (1998) }\end{array}$ & \\
\hline
\end{tabular}

\section{References}

Al Ganideh, S. (2012). Examining consumer ethnocentrism amongst Jordanians from an ethnic group perspective. International Journal of Marketing Studies, 4(1), 48-57.

Al-Wugayan, A., Pleshko, L., \& Baqer, S. (2008). An investigation of the relationships among consumer satisfaction, loyalty, and market share in Kuwaiti loan services. Journal of Financial Services Marketing, 13(2), 95-106.

Alpert, F., Kamins, M., Sakano, T., Onzo, N., \& Graham, J. (2001). Retail buyer beliefs, attitude and behavior toward pioneer and me-too follower brands: A comparative study of Japan and the USA. International Marketing Review, 18(2), 160-187.

Armstrong, G., \& Kotler, P. (2008). An introduction in marketing (12th ed.). Prentice Hall Inc. New Jersey.

Arnold, D. (2000). Seven rules of international distribution. Harvard Business Review, 78(6), 131-137.

Askegaard, S., \& Madsen, T. K. (1998). The local and the global: Exploring traits of homogeneity and heterogeneity in European food cultures. International Business Review, 7(6), 549-568.
Assad, S. (2007). The raise of consumerism in Saudi Arabian society. International Journal of Commerce and Management, 17(1/2), 73-104.

Attwood, E. (2012). First US brands win race to enter Libya. Arabian Business 2 August 2012. Available at http://www.arabianbusiness.com/first-us-brands-win-raceenter-libya-468360.html Accessed 27.07.14.

Balabanis, G., \& Diamantopoulos, A. (2004). Domestic country bias, country-oforigin effects, and consumer ethnocentrism: A multidimensional unfolding approach. Journal of the Academy of Marketing Science, 32(1), 80-95.

Balabanis, G., Mueller, R., \& Melewar, T. C. (2002). 'The human values' lenses of countryof-origin images. International Marketing Review, 19(6), 582-610.

Banerjee, S. (2007). Strategic brand-culture fit: A conceptual framework for brand management. Journal of Brand Management, 15(5), 312-321.

Barksdale, H. C., \& Darden, W. R. (1972). Consumer attitudes toward marketing and consumerism. Journal of Marketing, 36(October), 28L 35.

Birnik, A., \& Bowman, C. (2007). Marketing mix standardization in multinational corporations: A review of the evidence. International Journal of Management Reviews, 9(4), 303-324. 
Branding Korea (2012). Nation brand indexes and the Korea Brand, Part 1. Anholt-Gfk Roper NBI Available at http://brandingkorea.org/nation-brand-indexes-the-koreabrand-part-1-the-anholt-gfk-roper-nbi/ Accessed 13.05.12.

Brei, V., Avila, L., Camargo, L., \& Engels, J. (2011). The influence of adaptation and standardization of the marketing mix on performance: A meta-analysis. Brazilian Administration Review, 8(3), 266-287.

Brouthers, K., \& Brouthers, L. E. (2003). Why service and manufacturing entry mode choices differ: The influence of transaction cost factors, risk and trust. Journal of Management Studies, 40(5), 1179-1204.

Burns, R. P., \& Burns, R. (2008). Business research methods and statistics using SPSS. London: Sage Publications.

Busnaina, I., Youssef, J., \& Woodall, T. (2010). What does the consumer subculture connote? An Islamic perspective. 1st international conference on Islamic marketing and branding.

Calantone, R. J., Cavusgil, S. T., Schmidt, J. B., \& Shin, G.-C. (2004). Internationalization and the dynamics of product adaptation - An empirical investigation. Journal of Product Innovation Management, 21(3), 185-198.

Canabal, A., \& White, G. O., III (2008). Entry mode research: Past and future. International Business Review, 17(3), 267-284.

Cateora, P., \& Graham, J. (2005). International marketing (12th ed.). New York: McGrawHill Irwin.

Cayla, J., \& Arnould, E. (2008). A cultural approach to branding in the global marketplace. Journal of International Marketing, 16(4), 86-112.

Central Intelligence Agency (2010). The World Factbook. Available at https://www. cia.gov/library/publications/the-world-factbook/geos/xx.html\#Intro Accessed 16.04.12.

Chan, T. S., \& Cui, G. (2004). Consumer attitudes toward marketing in a transitional economy: A replication and extension. Journal of Consumer Marketing, 21(1), 10-26.

Chao, P. (1993). Partitioning country of origin effects: Consumer evaluations of a hybrid product. Journal of International Business Studies, 24(2), 291-306.

Cheng, J. M. S., Blankson, C., Wu, P., \& Chen, S. S. (2005). A stage model of international brand development: The perspectives of manufacturers from two newly industrialized economies-South Korea and Taiwan. Industrial Marketing Management, 34(5), 504-514.

Cheon, H. J., Cho, C. H., \& Sutherland, J. (2007). A meta-analysis of studies on the determinants of standardization and localization of international marketing and advertising strategies. Journal of International Consumer Marketing, 19(4), 109-147.

Chung, H. F. (2009). Structure of marketing decision making and international marketing standardization strategies. European Journal of Marketing, 43(5/6), 794-825.

Chung, C., \& Tsai, Q. (2009). The effects of regulatory focus and tie strength on word-ofmouth behavior. Asia Pacific Journal of Marketing and Logistics, 21(3), 329-341.

Cristel, R., \& Dale, R. (2010). Guilty by stereotypic association: Country animosity and brand prejudice and discrimination. Marketing Letters, 21(4), 413-425.

Darke, P., \& Ritchie, R. J. B. (2007). The defensive consumer: Advertising deception, defensive processing and distrust. Journal of Marketing Research, 44(1), 114-127.

d'Astous, A., \& Ahmed, S. A. (1999). The importance of country images in the formation of consumer product perceptions. International Marketing Review, 16(2), 108-126.

Dawar, N., \& Parker, P. (1994). Marketing universals: Consumers' use of brand name, price, physical appearance, and retailer reputation as signals of product quality. Journal of Marketing, 58(2), 81-95.

Dawar, N., Parker, P., \& Price, L. (1997). Border crossing: Is culture irrelevant to marketing? Impact Management Research in Action by the Ivey Business School, 3(2). Available at http://www.ivey.uwo.ca/publications/Impact/vol3_31.htm Accessed 01.04.12.

De Mooij, M. (2003). Convergence and divergence in consumer behavior: Implications for global advertising. International Journal of advertising, 22(2), 183-202.

De Mooij, M., \& Hofstede, G. (2002). Convergence and divergence in consumer behavior: Implications for international retailing. Journal of Retailing, 78(1), 61-69.

DeVellis, R. (2003). Scale development: Theory and applications. London: Sage Publications.

Dibb, S., Simkin, L., Pride, W., \& Ferrell, O. C. (2006). Marketing: Concepts and strategies (5th European edition). Boston, MA: Houghton Mifflin.

Dinnie, K. (2009). Repositioning the Korea brand to a global audience: Challenges, pitfalls, and current strategy. Korea Economic Institute America, Academic Pape Series, 4(9), 1-7.

Dinnie, K. (2011). The impact on country image of the North Africa and Middle East uprisings. Place Branding \& Public Diplomacy, 7(2), 79-80.

Djursaa, M., \& Kragh, S. U. (1998). Central and peripheral consumption contexts: The uneven globalization of consumer behavior. International Business Review, 7(1), 23-38.

Drogendijk, R., \& Slangen, A. (2006). Hofstede, Schwartz, or managerial perceptions? The effects of different cultural distance measures on establishment mode choices by multinational enterprises. International Business Review, 15(4), 361-380.

Elbashier, A. M., \& Nicholls, J. R. (1993). Export marketing in the Middle East: The importance of cultural differences. European Journal of Marketing, 17(1), 68-81.

Ellis, P. D., \& Zhan, G. (2011). How international are the international business journals? International Business Review, 20(1), 100-112.

Essoussi, L. H., \& Merunka, D. (2007). Consumers' product evaluations in emerging markets: Does country of design, country of manufacture, or brand image matter? International Marketing Review, 24(4), 409-426.

Ettenson, R. (1993). Brand name and country of origin effects in the emerging market economies of Russia, Poland, and Hungary. International Marketing Review, 10(5), $14-16$.

Fastoso, F., \& Whitelock, J. (2010). Regionalization vs. globalization in advertising research: Insights from five decades of academic study. Journal of International Management, 16(1), 32-42.
Fang, Y., Wade, M., Delios, A., \& Beamish, P. W. (2007). International diversification, subsidiary performance, and the mobility of knowledge resources. Strategic Management Journal, 28(10), 1053-1064.

Felzenstein, C., Hibbert, S., \& Vong, G. (2004). Is the country of origin the fifth element in the marketing mix of imported wine? A critical review of the literature. Journal of Food Products Marketing, 10(4), 73-84.

Gaski, J. (2008). The index of consumer sentiment toward marketing: Validation, updated results, and demographic analysis. Journal of Consumer Policy, 31(2), $195-216$.

Gaski, J., \& Etzel, M. (1986). The index of consumer sentiment toward marketing. Journal of Marketing, 50(3), 71-81.

Gaski, J., \& Etzel, M. (2005). National aggregate consumer sentiment toward marketing: A thirty-year retrospective and analysis. Journal of Consumer Research, 26(5), 481-495.

Ghanem, S., Kalliny, M., \& Elgoul, S. (2013). The impact of technology on the Arab communication style and culture: Implications for marketing. Journal of Marketing Communications, 19(5), 324-340.

Ghemawat, P., \& Thomas, C. (2008). Arcelik home appliances: International expansion strategy. Moston, MA: Harvard Business Publishing.

Gladwell, M. (2001). The tipping point: How little things can make a big difference. London: Abacus.

Griffith, D., Chandra, A., \& Ryans, J. (2002). Examining the intricacies of promotion standardization: Factors influencing advertising message and packaging. Journal of International Marketing, 11(3), 30-47.

Grzybek, P. (2012). Harry Dexter Kitson (1886-1959). Glottomterics, 24, 88-94 Available at http://www.peter-grzybek.eu/science/publications/2012/grzybek_2012_ kitson.pdf Accessed 10.05.13.

Hague, P., \& Jackson, P. (1992). Marketing research in practice. London: Kogan Page Limited.

Hall, E. T. (1976). Beyond culture. New York: Anchor Press/Doubleday.

Hallbäck, J., \& Gabrielsson, P. (2013). Entrepreneurial marketing strategies during the growth of international new ventures originating in small and open economies. International Business Review, 22(6), 1008-1020.

Harris, G., \& Attour, S. (2003). The international advertising practices of multinational companies: A content analysis study. European Journal of Marketing, 37(1/ 2), 154-168.

Helm, R., \& Gritsch, S. (2014). Examining the influence of uncertainty on marketing mix strategy elements in emerging business to business export-markets. International Business Review, 23(2), 418-428.

Herche, J. (1994). Measuring social values: A multi-items adaption to the list of values (working paper report number 94-101) Cambridge: Marketing Science Institute.

Hiraga, T. (2010). Global strategy of LG Electronics as a leading Korean company. Available at http://www.nli-research.co.jp/company/insurance/1009lg_electronics_eng.pdf Accessed 14.05.13.

Hise, R., \& Choi, Y. T. (2010). Are US companies employing standardization or adaptation strategies in their international markets? Journal of International Business \& Cultural Studies, 4, 1-29.

Hofstede, G. (2012). Insights on Hofstede's research into national and organizational culture; Arab World. Available at http://geert-hofstede.com/ arab-world-egiqkwlblysa.html Accessed 01.04.12.

Jain, S. (1989). Standardization of international marketing strategy: Some research hypotheses. Journal of Marketing, 53(1), 70-79.

Jarvis, C. B., McKenzie, S. B., \& Podsakoff, P. M. (2003). A critical review of construct indicators and measurement model misspecification in marketing and consumer research. Journal of Consumer Research, 30(2), 199-218.

Khakhar, P., \& Rammal, H. G. (2013). Culture and business networks: International business negotiations with Arab managers. International Business Review, 22(3), 578-590.

Kalliny, M., \& LeMaster, J. (2005). Before you go, you should know: The impact of war, economic, cultural and religious animosity on entry modes. Marketing Management Journal, 15(2), 18-28.

Karande, K., Almurshidee, K. A., \& Al-Olayan, F. S. (2006). Advertising standardization in culturally similar markets. International Journal of Advertising, 25(4), 489-511.

Katsikeas, C. S., Samiee, S., \& Theodosiou, M. (2006). Strategy fit and performance consequences of international marketing standardization. Strategic Management Journal, 27(9), 867-890.

Katzenstein, P. J., \& Keohane, R. O. (2007). Anti-Americanisms in world politics. New York: Cornell University Press.

Kefalas, A. G. (1998). Think globally, act locally. Thunderbird International Business Review, 40(60), 547-562.

Kemp-Benedict, E. (2009). Converting qualitative assessments to quantitative assumptions: Bayes' rule and the pundit's wager. Technological Forecasting \&' Social Change, 77(1), 167-171.

Khraim, H., Khraim, S., Salim, A., Al-Kaidah, F., \& Al-Qurashi, D. (2011). Jordanian consumer's evaluation of retail store attributes: The influence of consumer religiosity. International Journal of Marketing Studies, 3(4), 105-116.

Klein, J. G. (2002). Us versus them, or us versus everyone? Delineating consumer aversion to foreign goods. Journal of International Business Studies, 33(2), 345-363.

Knight, G. (1999). Consumer preferences for foreign and domestic products. Journal of Consumer Marketing, 16(2), 151-162.

Kotler, P. (1986). Global standardization - Courting danger. Journal of Consumer Marketing, 3(2), 13-15.

Kotler, P. (1999). Kotler on marketing. New York: Free Press.

Kotler, P. (2003). Marketing management: International edition (11th ed.). New Jersey: Prentice Hall Inc.

Kotler, P. (2005). According to Kotler. New York: American Management Association. 
Kotler, P., \& Gertner, D. (2002). Country as brand, product, and beyond: A place marketing and brand management perspective. Journal of Brand Management, 9(4), 249-261.

Koubaa, Y. (2008). Country of origin, brand image perception, and brand image structure. Asia Pacific Journal of Marketing and Logistics, 19(3), 139-155.

KPMG (2013). Why invest in Libya?. In Insight (October, pp. 14-17).

Krejcie, R., \& Morgan, D. (1970). Determining sample size for research. Educational and Psychological Measurement, 70, 607-610.

Kustin, R. A. (2004). Marketing mix standardization: A cross cultural study of four countries. International Business Review, 13(5), 637-649.

Kustin, R. (2010). The earth is flat, almost: Measuring marketing standardization and profit performance of Japanese and U.S. firms. Journal of Global Marketing, 23(2), 100-108.

Lages, L. F., Abrantes, J. L., \& Lages, C. R. (2008). The STRATADAPT scale: A measure of marketing strategy adaptation to international business markets. International Marketing Review, 25(5), 584-600.

Lages, L. F., Silva, G., \& Styles, C. (2009). Relationship capabilities, quality, and innovation as determinants of export performance. Journal of International Marketing, 17(4), 47-70.

Lee, J. Y., \& MacMillan, I. C. (2008). Managerial knowledge-sharing in chaebols and its impact on the performance of their foreign subsidiaries. International Business Review, 17(5), 533-545.

Levitt, T. (1983). The globalization of markets. Harvard Business Review, 61(3), 2-11.

Lindridge, A., \& Dibb, S. (2003). Is culture a justifiable variable for market segmentation? A cross-cultural example. Journal of Consumer Behavior, 2(3), 269-286.

Lopez, M., Gotsi, C., \& Andriopoulos, C. (2011). Building country image through corporate image: Exploring the factors that influence the image transfer. Journal of Strategic Marketing, 19(3), 255-272.

Luna, D., \& Gupta, F. (2001). An integrative framework for cross-culture consumer behavior. International Marketing Review, 18(1), 45-69.

Lundstrom, W., Lee, O., \& White, S. (1998). Factors influencing Taiwanese consumer preference for foreign-made white goods: USA versus Japan. Asia Pacific Journal of Marketing and Logistics, 10(3), 5-29.

Lysonski, S., Durvasula, S., \& Watson, J. (2003). Should marketing managers be concerned about attitudes towards marketing and consumerism in New Zealand? A longitudinal view. European Journal of Marketing, 37(3/4), 385-406.

Mady, T., Cherrier, H., Lee, D., \& Rahman, K. (2011). Can sentiment toward advertising explain materialism and vanity in the globalization era? Evidence from Dubai. Journal of Global Marketing, 24(5), 453-472.

Magnusson, P., Westjohn, S. A., \& Zdravkovic, S. (2011). What? I thought Samsung was Japanese: Accurate or not, perceived country of origin matters. International Marketing Review, 28(5), 454-472.

Mahajan, V. (May 2013). Understanding the Arab consumer. Harvard Business Review (Online) Available at http://hbr.org/2013/05/understanding-the-arab-consumer/ ar/1 Accessed 30.04.13.

Marinov, M. (2007). Marketing in the emerging markets of Islamic countries. New York: Palgrave MacMillan.

Melewar, T. C., Turnbull, S., \& Balabanis, G. (2000). International advertising strategies of multinational enterprises in the Middle East. International Journal of Advertising, 19(4), 529-547.

Melewar, T., \& Vemmervik, C. (2004). International advertising strategy: A review, reassessment and recommendation. Management Decision, 42(7), 863-881.

Metz, H. (1987). Libya: A country study. Washington: GPO for the Library of Congress, USA Available at http://countrystudies.us/libya Accessed 01.04.12.

Michell, P., Lynch, J., \& Alabdali, O. (1998). New perspectives on marketing mix programme standardization. International Business Review, 7(6), 617-634.

Ministry of Economy: Libya (2013). The proposal of developing commercial and companies' laws. Available at http://www.ect.gov.ly/index.php/component/forme/?fid=6 Accessed 21.05.13.

Mostafa, M. M. (2011). An investigation of Egyptian consumers' attitudes toward ethical issues in advertising. Journal of Promotion Management, 17(1), 42-60.

Navarro, A., Losada, F., Ruzo, E., \& Díez, J. A. (2010). Implications of perceived competitive advantages, adaptation of marketing tactics and export commitment on export performance. Journal of World Business, 45(1), 49-58.

Okechuku, C., \& Onyemah, V. (1999). Nigerian consumer attitudes toward foreign and domestic products. Journal of International Business Studies, 30(3), 61-622.

Ozsomer, A., Bodur, M., \& Cavusgil, T. (1991). Marketing standardization by multinationals in an emerging market. European Journal of Marketing, 25(12), 50-64.

Ozsomer, A., \& Simonin, B. (2004). Marketing programme standardization: A crosscountry exploration. International Journal of Research in Marketing, 21(4), 397-419.

Park, Y. W., Shintaku, J., \& Amano, T. (2010). Korean firm's competitive advantage: Localization strategy of LG Electronics (No. 292). Discussion Paper. Available at http:// merc.e.u-tokyo.ac.jp/mmrc/dp/pdf/MMRC292_2010.pdf Accessed 24.04.13.

Pavlos, V., Vrechopoulos, A., \& Doukidis, G. (2002). Exploring consumer attitudes towards mobile music services. International Journal on Media Management, 5(2), 138-148.

Peter, J. P., \& Olson, J. C. (2008). Consumer behavior and marketing strategy. New York: McGraw-Hill.

Peterson, M., \& Ekici, A. (2007). Consumer attitude toward marketing and subjective quality of life in the context of a developing country. Journal of Macromarketing 27(4), 350-359.

Phau, I., \& Prendergast, G. (2000). Conceptualizing the country of origin of brand Journal of Marketing Communications, 6(3), 159-170.

Porter, M. (2007). Michael Porter on Libya's Potential: The Harvard professor talks about the country's dependency economy and his work to promote reform, by Stanley Reed. BusinessWeek February 23. Available at www.businessweek.com/ globalbiz/content/feb2007/gb20070223_828554.htm?campaignid=rss_daily Accessed 01.04.12.
Powers, T., \& Loyka, J. (2007). Market, industry, and company influences on global product standardization. International Marketing Review, 24(6), 678-694.

Powers, T. L., \& Loyka, J. J. (2010). Adaptation of marketing mix elements in international markets. Journal of Global Marketing, 23(1), 65-79.

Rafiq, M., \& Ahmed, P. (1995). Using the 7Ps as a generic marketing mix: An exploratory survey of UK and European marketing academics. Marketing Intelligence and Planning, 13(9), 4-15.

Rahman, Z., \& Bhattacharyya, S. K. (2003). First mover advantages in emerging economies: A discussion. Management Decision, 42(2), 141-147.

Rennack, D. (2006). Libya: Legislative Basis for U.S. Economic Sanctions. USA: Congressional Research Service-The Library of Congress Available at http://digital.library unt.edu/ark:/67531/metacrs8687/m1/1/high_res_d/RL32604_2006Jan23.pdf Accessed 01.04.12.

Reynaldo, J., \& Santos, A. (1999). Cronbach's alpha: A tool for assessing the reliability of scales. Journal of Extension, 37(2), 1-7.

Rosenbloom, B., Larsen, T., \& Mehta, R. (1997). Global marketing channels and the standardization controversy. Journal of Global Marketing, 11(1), 49-64.

Rosenbloom, A., \& Haefner, J. E. (2009). Country-of-origin effects and global brand trust: A first look. Journal of Global Marketing, 22(4), 267-278.

Roth, M. S. (1995). The effects of culture and socioeconomics on the performance of global brand image strategies. Journal of Marketing Research, 32(2), 163-175.

Sandler, D., \& Shani, D. (1992). Brand globally but advertise locally? An empirical investigation. International Marketing Review, 9(4), 18-31.

Schmid, S., \& Kotulla, T. (2011). 50 years of research on international standardization and adaptation - From a systematic literature analysis to a theoretical framework. International Business Review, 20(5), 491-507.

Schuh, A. (2000). Global standardization as a success formula for marketing in Central Eastern Europe? Journal of World Business, 35(2), 133-148.

Shaw, V., \& Richter, T. (1999). Marketing Mix Standardization: Preliminary Finding from the Top 500 German and British Companies. ANZMAC99, 4-6. Available at http://smib.vuw.ac.nz:8081/www/ANZMAC1999/Site/S/Shaw.pdf Accessed 01.04.12.

Shoham, A., \& Brencic, M. (2003). Compulsive buying behavior. Journal of Consumer Marketing, 20(2), 127-138

Shoham, A., Brencic, M., Virant, V., \& Ruvio, A. (2008). International standardization of channel management and its behavioral and performance outcomes. Journal of International Marketing, 16(2), 120-151.

Siraliova, J., \& Angelis, J. (2006). Marketing strategy in the Baltics: Standardize or adapt? Baltic Journal of Management, 1(2), 169-187.

Solberg, C. A. (2000). Standardization or adaptation of the international marketing mix: The role of the local subsidiary/representative. Journal of International Marketing 8(1), 78-98.

Solberg, C. A. (2002). The perennial issue of adaptation or standardization of international marketing communication: Organizational contingencies and performance. Journal of International Marketing, 10(3), 1-21.

Souiden, N. (2000). Is marketing standardization feasible among Arab countries? Journal of International Marketing and Marketing Research, 25(2), 69-94.

Souiden, N. (2002). Segmenting the Arab markets on the basis of marketing stimuli. International Marketing Review, 19(9), 611-636.

Srinivasan, N., Jain, S. C., \& Sikand, K. (2004). An experimental study of two dimensions of country-of-origin (manufacturing country and branding country) using intrinsic and extrinsic cues. International Business Review, 13(1), 65-82.

Steenkamp, J., \& Hofstede, F. (2002). International market segmentation: Issues and perspectives. International Journal of Research in Marketing, 19(3), 185-213.

Stottinger, B., \& Schlegelmilch, B. B. (1998). Explaining export development through psychic distance: Enlightening or elusive? International Marketing Review, 15(5), 357-372.

Svensson, G. (2002). Beyond global marketing and the globalization of marketing activities. Management Decision, 40(6), 574-583.

Tan, Q., \& Sousa, C. M. P. (2013). International marketing standardization: A metaanalytic estimation of its antecedents and consequences. Management International Review March. Available at http://link.springer.com/article/10. 1007\%2Fs11575-013-0172-5 (acceded 21.05.13).

Taylor, C., Zou, S., \& Osland, G. (2000). Foreign market entry strategies of Japanese MNCs. International Marketing Review, 17(2), 146-163.

Teng, L., Laroche, M., \& Zhu, H. (2007). The effect of multiple-ads and multiplebrands on consumer attitude and purchase behavior. Journal of Consumer Marketing, 24(1), 27-55.

Theodosiou, M., \& Katsikeas, C. (2001). Factors influencing the degree of international pricing strategy standardization of multinational corporations. Journal of International Marketing, 9(3), 1-18.

Theodosiou, M., \& Leonidou, L. C. (2003). Standardization versus adaptation of international marketing strategy: An integrative assessment of the empirical research. International Business Review, 12(2), 141-171.

Tolba, A. (2011). The impact of distribution intensity on brand preference and brand loyalty. International Journal of Marketing Studies, 3(3), 56-66.

US, \& FCS (2006). Doing Business in Libya: A Country Commercial Guide for U.S. Companies. U.S. E Foreign Commercial Service and U.S. Department of State, 17-47 March 2006. Available at http://libya.usembassy.gov/uploads/images/ Ctlb_B9GauiYq1ai9cp4AQ/021108_-_2008_Country_Commercial_Guide.pdf Accessed 01.04.12.

Usunier, J. (2000). Marketing across cultures. United Kingdom: Pearson Education Limited.

Varadarajan, P. R., \& Thirunarayara, P. N. (1990). Consumers' attitudes towards marketing practices, consumerism and government regulations: Cross-national perspectives. European Journal of Marketing, 24(6), 6-23. 
Venaik, S., \& Brewer, P. (2013). Critical issues in the Hofstede and GLOBE national culture models. International Marketing Review, 30(5), 469-482.

Vigneron, F., \& Johnson, L. (1999). A Review and a Conceptual Framework of PrestigeSeeking Consumer Behavior. Academy of Marketing Science Review, 1. Available at http://www.amsreview.org/articles/vigneron01-1999.pdf Accessed 01.04.12.

Virvilaite, R., Seinauskiene, B., \& Sestokiene, G. (2011). The link between standardization/adaptation of international marketing strategy and company performance. Engineering Economics, 22(1), 106-117.

Viswanathan, N., \& Dickson, P. (2007). The fundamentals of standardization global marketing strategy. International Marketing Review, 24(1), 46-63.

Vrontis, D., Thrassou, A., \& Lamprianou, I. (2009). International marketing adaptation versus standardization of multinational companies. International Marketing Review, 26(4/5), 477-500.

Waheeduzzaman, A. N. M. (2006). Can modernization explain the consumption of durables in emerging markets? Journal of Global Marketing, 19(3/4), 33-62.

Whitelock, J., \& Jobber, D. (2000). An exploratory investigation into the impact of competitor environment and the role of information on the decision to enter a new, non-domestic market. Journal of Global Marketing, 13(2), 67-83.

Wooldridge, A. (2010). The emerging markets. The Economist Nov 22nd. Available at http://www.economist.com/node/17493411 Accessed 14.02.13.

Yildiz, H. E., \& Fey, C. F. (2012). The liability of foreignness reconsidered: New insights from the alternative research context of transforming economies. International Business Review, 21(2), 269-280.

Zabadi, A., Shura, A., \& Elsayed, M. (2012). Consumer attitudes toward SMS Advertising among Jordanian users. International Journal of Marketing Studies, 4(1), 77-94.

Zou, S., \& Cavusgil, T. (1996). Global strategy: A review and an integrated conceptua framework. European Journal of Marketing, 30(1), 52-69.
Zou, S., \& Cavusgil, S. T. (2002). The GMS: A broad conceptualization of global marketing strategy and its effect on firm performance. Journal of Marketing, 66(4), 40-56.

Izzudin Busnaina is an Assistant Professor of Marketing in the Faculty of Economics, University of Benghazi and visiting Assistant professor at Tunis Business School. His teaching areas are; marketing management' marketing communications and research. Izzudin's primary research interests concern the design of marketing programs across the world and, particularly, their effect on consumer buying behavior in MENA (Middle East/North Africa) countries. Recently, he has focused on the feasibility of existing consumer behavior models in MENA context and on the nature/impact of global brand perceptions. He has contributed to several international marketing conferences via both practical research papers and seminars on these issues in the UK, Canada, Malaysia, Jordan, Libya, Dubai and Tunisia.

Tony Woodall is a Principal Lecturer in Marketing at Nottingham Business School, Nottingham Trent University. His major teaching focus is on post-purchase consumer behavior and research interests include how consumers aggregate, experience and perceive service value; the nature/role of both marketing and the marketer in contemporary organizations; and the nature and diversity of consumer behavior in differing cultural contexts. He has published in a range of academic journals including the European Journal of Marketing, the Academy of Marketing Science Review, the Journal of Marketing Management, the Journal of Strategic Marketing, Studies in Higher Education and Marketing Theory. 